\author{
UNIVERSIDADE DE SÃO PAULO \\ FACULDADE DE ODONTOLOGIA DE BAURU
}

BRUNA BOTTEON DELLA COLETTA

Effects of photobiomodulation therapy on guided bone regeneration in defects filled by biphasic calcium phosphate associated with fibrin biopolymer

Efeitos da terapia por fotobiomodulação no processo de regeneração óssea guiada em defeitos preenchidos por fosfato de cálcio bifásico associado ao biopolímero de fibrina

BAURU

2020 



\section{Effects of photobiomodulation therapy on guided bone regeneration in defects filled by biphasic calcium phosphate associated with fibrin biopolymer}

Efeitos da terapia por fotobiomodulação no processo de regeneração óssea guiada em defeitos preenchidos por fosfato de cálcio bifásico associado ao biopolímero de fibrina

Dissertação constituída por artigo apresentada à Faculdade de Odontologia de Bauru da Universidade de São Paulo para obtenção do título de Mestre em Ciências no programa de Ciências Odontológicas Aplicadas na área de concentração Biologia Oral.

Orientador: Prof. Dr. Rogério Leone Buchaim 


\section{Coletta, Bruna Botteon Della}

Effects of photobiomodulation therapy on guided bone regeneration in defects filled by biphasic calcium phosphate associated with fibrin biopolymer/ Bruna Botteon Della Coletta. -- Bauru, 2020.

70 p. : il. ; $31 \mathrm{~cm}$.

Dissertação (Mestrado) -- Faculdade de Odontologia de Bauru, Universidade de São Paulo, 2020

Orientador: Prof. Dr. Rogério Leone Buchaim

Autorizo, exclusivamente para fins acadêmicos e científicos, a reprodução total ou parcial desta dissertação/tese, por processos fotocopiadores e outros meios eletrônicos.

Assinatura: BRUNA BOTTEON DELLA COLETTA

Data: $13 / 10 / 2020$

Comitê de Ética da UNIMAR

Protocolo no: 04/2018

Data: $28 / 06 / 2018$ 
ERRATA 

FOLHA DE APROVAÇÃO 



\section{AGRADECIMENTOS}

À minha família, meus pais, Mateus Della Coletta e Cristiane Boteon Della Coletta, meu irmão, Mateus Boteon Della Coletta, pelo incentivo e por estarem sempre presentes. Ao Felipe Nascimento Sousa, meu companheiro de vida, sempre comigo em todos os momentos, me apoiando e sonhando junto. Dedico a eles este trabalho.

Ao meu orientador, Rogério Leone Buchaim, pela oportunidade de desenvolver um trabalho em seu grupo de pesquisa, pela orientação, por todo aprendizado e confiança depositada em mim.

Ao professor Jesus Carlos Andreo, sempre disposto a ajudar no que fosse preciso, obrigada pelo carinho e atenção.

Aos amigos que fiz no laboratório de Anatomia, Karina Torres Pomini Rocha, Marcelie Priscila de Oliveira Rosso e João Victor Tadashi Cosin Shindo, pela companhia de todos os dias, pela ajuda na pesquisa, em especial à Karina, por todo auxílio e ensinamentos que foram fundamentais para o desenvolvimento da dissertação.

Aos alunos e professores da Universidade de Marília (Unimar) que fizeram parte do delineamento experimental dessa pesquisa, pela parceria e comprometimento durante todo o processo. 



\section{AGRADECIMENTOS INSTITUCIONAIS}

"O presente trabalho foi realizado com o apoio da Coordenação de Aperfeiçoamento de Pessoal de Nível Superior - Brasil (CAPES) - Código de Financiamento 001".

À Faculdade de Odontologia de Bauru da Universidade de São Paulo (FOB USP).

Ao Prof. Dr. Vahan Agopyan, digníssimo Reitor da Universidade de São Paulo.

Ao Prof. Dr. Pedro Vitoriano Oliveira, digníssimo secretário Geral da Universidade de São Paulo.

Ao Prof. Dr. Carlos Ferreira dos Santos, digníssimo Diretor da Faculdade de Odontologia de Bauru da Universidade de São Paulo.

Ao Prof. Dr. Guilherme dos Reis Pereira Janson, digníssimo Vice-Diretor da Faculdade de Odontologia de Bauru da Universidade de São Paulo.

Ao Prof. Dr. José Roberto Pereira Lauris, digníssimo Prefeito do Campus da Faculdade de Odontologia de Bauru da Universidade de São Paulo.

À Profa. Dra. Izabel Regina Fischer Rubira Bullen, digníssima Coordenadora do Programa de Pós-Graduação em Ciências Odontológicas Aplicadas e Presidente 

da Comissão de Pós-Graduação na área de Estomatologia e Biologia Oral, da Faculdade de Odontologia de Bauru da Universidade de São Paulo.

A parceria com a Universidade de Marília - Unimar;

Ao Centro de Estudos de Venenos e Animais Peçonhentos (CEVAP) da Unesp Botucatu, juntamente com os Professores Doutores Benedito Barraviera e Rui Seabra Ferreira Júnior por permitirem o desenvolvimento de mais esta pesquisa utilizando o biopolímero de fibrina cedendo-o para nosso grupo de estudos. 



\section{ABSTRACT \\ Effects of photobiomodulation therapy on guided bone regeneration in defects filled by biphasic calcium phosphate associated with fibrin biopolymer}

Bone tissue has an intrinsic regenerating property and can be renewed without any intervention. However, depending on the size of the lesion, as a result of trauma, modifications, tumors, necrosis, the repair may be impaired, requiring bone substitutes to assist in the remodeling process. As a result, interest in research in the area of tissue engineering grew in order to develop biomaterials and capable rehabilitation methods to facilitate the growth of new bone. Thus, the objective of this work was to present an experimental research article to evaluate the effects of laser photobiomodulation therapy on the guided bone regeneration process in rats' skullcap defects, filled with a hydroxyapatite and beta biomaterial compound tricalcium phosphate associated with the heterologous fibrin three-dimensional biopolymer scaffold. Thirty male Wistar rats were used, randomly separated into three groups: BMG $(n=10)$, with defects filled with biomaterial and covered by membrane; BFMG $(n=10)$, with defects filled with biomaterial and fibrin biopolymer, covered by membrane, and BFMLG $(n=10)$, with defects filled with biomaterial and fibrin biopolymer, covered by membrane and biostimulated with laser. The animals were euthanized at 14 and 42 days after the operation. Through microtomography analyzes and histological images stained by Masson's trichrome and hematoxylin and eosin, it was possible to observe that this is a critical size defect, as there was no complete closure of the surgical area by bone tissue, and all groups, at the end of the experimental period, they showed particles of the biomaterial. Histomorphometrically, all groups showed an exponential increase in bone neoformation, however the group with associated biomaterials together with laser photobiomodulation therapy, GBFML, showed a more evident increase. In the analysis of the birefringence of collagen fibers, all groups showed deposition of collagen fibers throughout the experimental period, with a color transition to yellow-green after the 42 days, characterized by the lamellar bone. It is concluded that the results of the present study show that a laser photobiomodulation therapy provided positive effects on guided bone regeneration when associated with fibrin biopolymer and biphasic calcium phosphate, accelerating the remodeling process in critical rats calvaria defects. 

Keywords: Bone regeneration. Bone substitutes. Fibrin tissue adhesive. Laser therapy. 



\section{RESUMO}

\section{Efeitos da terapia por fotobiomodulação no processo de regeneração óssea guiada em defeitos preenchidos por fosfato de cálcio bifásico associado ao biopolímero de fibrina}

O tecido ósseo possui a propriedade intrínseca de regeneração, podendo ser renovado sem qualquer intervenção. No entanto, dependendo do tamanho da lesão, como resultado de traumas, infecções, tumores, necroses, o reparo pode ser prejudicado, necessitando de substitutos ósseos para ajudar no processo de remodelação. Com isso, cresceu o interesse por pesquisas na área da engenharia tecidual, a fim de desenvolver biomateriais e métodos reabilitadores capazes de facilitar o crescimento do novo osso. Desta forma, o objetivo deste trabalho foi apresentar um artigo de pesquisa experimental para avaliar os efeitos da terapia por fotobiomodulação a laser no processo de regeneração óssea guiada em defeitos de calota craniana de ratos, preenchidos por um composto de biomaterial à base de hidroxiapatita e beta fostato tricálcico associado ao andaime tridimensional biopolímero de fibrina heterólogo. Foram utilizados 30 ratos machos da linhagem Wistar, separados aleatoriamente em três grupos: GBM $(n=10)$, com defeitos preenchidos com biomaterial e recobertos por membrana; GBFM ( $n=10)$, com defeitos preenchidos com biomaterial e biopolímero de fibrina, recobertos por membrana, e GBFML ( $n=10)$, com defeitos preenchidos com biomaterial e biopolímero de fibrina, recobertos por membrana e bioestimulados com laser. Os animais foram eutanasiados aos 14 e 42 dias do pós-operatório. Por meio das análises realizadas por microtomografia e as imagens histológicas coradas por tricrômico de Masson e hematoxilina e eosina, foi possível observar que se trata de defeito de tamanho crítico, pois não houve fechamento completo da área cirúrgica por tecido ósseo, e todos os grupos, ao fim do período experimental, apresentaram partículas do biomaterial. Histomorfometricamente, todos os grupos apresentaram aumento exponencial de neoformação óssea, porém o grupo com os biomateriais associados juntamente com a terapia por fotobiomodulação a laser, GBFML, apresentou um aumento mais evidente. $\mathrm{Na}$ análise da birrefringência das fibras colágenas, todos os grupos mostraram depósito de fibras colágenas durante todo o período experimental, 

havendo transição de cor para verde-amarelado ao fim dos 42 dias, caracterizado pelo osso lamelar. Conclui-se que os resultados do presente estudo mostram que a terapia por fotobiomodulação a laser proporcionou efeitos positivos na regeneração óssea guiada quando associada ao biopolímero de fibrina e ao fosfato de cálcio bifásico, acelerando o processo de remodelação em defeitos críticos de calvária de ratos.

Palavras-chave: Regeneração óssea. Adesivo tecidual de fibrina Terapia a laser. 

TABLE OF CONTENTS

2 ARTICLE

2.1 ARTICLE 1

3 DISCUSSION

4 CONCLUSION

REFERENCES

ANNEXES. 

1 INTRODUCTION 



\section{INTRODUCTION}

Bone tissue has a great capacity for self-regeneration and remodeling, however, in the face of extensive defects caused by infections, trauma or genetic disorders, it cannot return to its original structure, requiring surgical interventions (GARCÍA-GARETA; COATHUP; BLUNN, 2015).

In these cases, autologous grafting has been the first choice since it posseses properties such as osteoinduction and osteoconduction, which favor bone formation (DIMITRIOU et al., 2012). However, given some limitations such as the limited amount of graft available, the need for additional surgery and the risk of damage to the donor area, synthetic biomaterials have been developed as a promising alternative to assist the bone repair of extensive defects (LEGEROS, 2008; SAKKAS et al., 2017).

Calcium phosphates, such as hydroxyapatite (HA) and beta calcium triphosphate $(\beta-T C P)$ are ceramic biomaterials used as bone substitutes due to their biocompatibility with the injured tissue, biodegradability, atoxicity and accessibility, factors that contribute to the formation of new bone with favorable results. (DOROZHKIN, 2010; SALINAS; VALLET-REGI, 2013).

The association of these bioceramics, HA and $\beta-T C P$, has been analyzed in the field of tissue engineering since they present synergistic effects on the overall result of the composite. This is possible because hydroxyapatite has excellent osteoconductive properties due to the similarity with the inorganic portion of human bone, which provides cellular support throughout the repair process. $\beta$-TCP, since it presents a faster rate of degradation, is able to release calcium and phosphate ions into the environment, favoring conditions for osteogenesis (VAN BLITTERSWIJK et al., 1986; LEGEROS, 2008; DOROZHKIN, 2012).

Since they are synthetic composites, the manipulation of their proportions is possible to control their rate of bioactivity and biodegradation. In previous studies, different ratios of biphasic calcium phosphate, BCP $(85 / 15,70 / 30,65 / 35,75.25$, 15/85), have been analyzed with different results (JENSEN et al., 2009; EBRAHIMI; BOTELHO; DOROZHKIN, 2017).

In the quest to optimize bone regeneration and provide a scaffold for the graft, a bioproduct that mimics the last stage of the blood coagulation cascade, known as fibrin sealant, has been studied in bone reconstruction due to its ability to act as a 
three-dimensional matrix, be biodegradable and biocompatible with the extracellular tissue (CUNHA et al., 2015; STRATTON et al., 2016; CASSARO et al., 2019).

In the 1990s, a group of researchers from the Center for the Study of Venoms and Venomous Animals (CEVAP) of the Sao Paulo State University (UNESP / Botucatu) developed a bioproduct purified from the snake venom, Crotalus durissus terrificus, called heterologous fibrin sealant for repair of nerve injuries and venous ulcers that, in addition to their bioadhesive and hemostatic properties, currently demonstrated several applications and was referred to as the heterologous fibrin biopolymer, FBP (BARROS et al., 2009; FERREIRA et al., 2013).

The satisfactory clinical and pre-clinical results have made this biopolymer an alternative to commercial counterparts due to the low risk of transmission of infectious diseases, the ease of application and the low cost of production (BARROS et al., 2009; FERREIRA et al., 2017; BUCHAIM et al., 2019).

In addition to trying to favor the formation of new bone, the mechanical barriers, more commonly referred to as guided bone regeneration (GBR), have been used in bone defects treated with particulate grafts to isolate the defect site, allowing the transport of plasma and nutrients and prevent invasion of non-osteogenic cells (GENTILE et al., 2011; GERBI et al., 2018).

Among the types of membranes, biodegradable ones are the most usedsince they do not require a second surgery for removal, are easier to handle, pose less risk of rejection and are resorbable (RETZEPI; DONOS, 2010; ELGALI et al., 2017).

Combined with tissue reconstruction procedures and to accelerate the regeneration process, laser photobiomodulation therapy (PBMT) is the target of extensive analysis in different areas of medicine, physiotherapy and dentistry since it is a safe, non-invasive and easy to handle tool capable of reducing inflammation and stimulating cell proliferation (LIU et al., 2007; CHUNG et al., 2012; BUCHAIM et al., 2017; MUSSTTAF; JENKINS; JHA, 2019; ROSSO et al., 2019).

Studies using Aluminum Gallium Arsenide (AlGaAs) lasers with a wavelength of $830 \mathrm{~nm}$ demonstrated the ability of laser radiation to modulate the inflammatory response to accelerate cell metabolism by increasing the concentration of adenosine triphosphate (ATP), increasing the synthesis of collagen fibers, and consequently, the deposition of an osteoid matrix when compared to groups not treated 
by laser (KUBOTA; OHSHIRO, 2004; PINHEIRO; GERBI, 2006; DE OLIVEIRA GONÇALVES et al., 2016).

Due to the absence of studies that used the biphasic (synthetic) ceramic bone graft composed of hydroxyapatite and calcium $\beta$-triphosphate in the proportion of $70 \%-30 \%$, associated with fibrin biopolymer, bone membrane and photobiomodulation therapy, the present research to evaluate the effects of laser photobiomodulation therapy (PBMT) on the bone regeneration process guided by critical defects in the calvary of rats is justified. 

2 ARTICLE 



\section{ARTICLE}

The article presented in the present dissertation was written according to the formatting guidelines for submission to the Journal of Venomous Animals and Toxins including Tropical Diseases (JVATiTD).

Article 1 - "Effects of photobiomodulation therapy on the bone regeneration process

guided in defects filled by biphasic calcium phosphate associated with fibrin biopolymer." 


\subsection{ARTICLE - "Effects of photobiomodulation therapy on the bone regeneration} process guided in defects filled by biphasic calcium phosphate associated with fibrin biopolymer"

\section{ABSTRACT}

Background: The compromise of the skeletal architecture limits bone regeneration, requiring the use of reconstructive treatments to assist the repair process. The aim of the present study was to evaluate the effects of laser photobiomodulation therapy (PBMT) on the bone regeneration process guided in defects in the skull cap of rats filled with biphasic calcium phosphate associated with fibrin biopolymer. Methods: Thirty male Wistar rats were randomly separated: BMG $(n=10)$, defects filled with biomaterial and covered by membrane; BFMG $(n=10)$, biomaterial and fibrin biopolymer covered by membrane, and BFMLG $(n=10)$, biomaterial and fibrin biopolymer covered by membrane and biostimulated with laser. The animals were euthanized at 14 and 42 days postoperatively and the caps were processed for analysis. Results: Microtomographically, at the end of the experiment there was bone growth, more evident in the BFMLG, but limited to the margins of the defect, without complete closure of the lesion and with permanence of the particles. Histomorphologically, it was possible to notice the presence of an inflammatory infiltrate which receded to 42 days with the formation of mineralized bone tissue. In the quantification of bone tissue, all groups had a progressive increase in new bone tissue with a significant difference in which the BFMLG showed greater bone formation in both periods $(10.12 \pm 0.67$ and $13.85 \pm 0.54)$, followed by BFMG $(7.35 \pm 0.66$ and 9.41 $\pm 0.84)$ and $B M G(4.51 \pm 0.44$ and $7.11 \pm 0.44)$. Picrosirius-red staining showed greater birefringence of collagen fibers in yellow-green color in the BFMLG, showing more advanced bone maturation. Conclusion: It was concluded that the laser application associated with biphasic calcium phosphate and fibrin biopolymer contributed to better results, accelerating the repair process. This suggests that laser photobiomodulation therapy may be indicated as a supporting method in guided bone regeneration.

Keywords: Bone regeneration. Bone substitutes. Fibrin tissue adhesive. Laser therapy. 


\section{Effects of photobiomodulation therapy on the bone regeneration process} guided in defects filled by biphasic calcium phosphate associated with fibrin biopolymer

Bruna Botteon Della Coletta ${ }^{1}$ | Thiago Borges Jacob², Luana Aparecida de Carvalho Moreira $^{2}$, Karina Torres Pomini Rocha ${ }^{3}$, Daniela Vieira Buchaim²,3,4, Rachel Gomes Eleutério ${ }^{2}$, Domingos Donizeti Roque ${ }^{2}$, Marcelie Priscila de Oliveira Rosso ${ }^{1}$, João Vitor Tadashi Cosin Shindo ${ }^{1}$, Murilo Priori Alcalde ${ }^{5}$, Marco Antônio Húngaro Duarte ${ }^{5}$, Rui Seabra Ferreira Júnior ${ }^{6,7}$, Benedito Barraviera ${ }^{6,7} \mid$ Rogério Leone Buchaim ${ }^{1,2,3^{\star}}$

${ }^{1}$ Department of Biological Sciences (Anatomy), Bauru School of Dentistry, University of São Paulo (USP), Bauru, SP, Brazil.

${ }^{2}$ Medical and Dentistry School, University of Marilia (UNIMAR), Marília, SP, Brazil.

${ }^{3}$ Postgraduate Program in Structural and Functional Interactions in Rehabilitation, University of Marilia (UNIMAR), Marília, SP, Brazil.

${ }^{4}$ Medical School, University Center of Adamantina (UniFAI), 17800-000, Adamantina; ${ }^{5}$ Department of Dentistry, Endodontics and Dental Materials, Bauru School of Dentistry, University of São Paulo (USP), Bauru, SP, Brazil.

${ }^{6}$ Center for the Study of Venoms and Venomous Animals (CEVAP), Sao Paulo State University (UNESP), Botucatu, SP, Brazil.

${ }^{7}$ Botucatu Medical School (FMB), Sao Paulo State University (UNESP), Botucatu, SP, Brazil. 


\section{INTRODUCTION}

Bone has a high intrinsic capacity for regeneration as part of the repair process in response to injuries and in degenerative diseases, restoring its original structure and mechanical properties [1,2]. However, when the skeletal architecture is compromised due to extensive bone defects, trauma, infections, tumor resection, skeletal abnormalities, avascular necrosis and osteoporosis, bone regeneration becomes limited [3].

When bone repair is impaired or insufficient, reconstructive treatments are needed to assist the compromised physiological process, with autologous grafting being the main technique employed due to its combined properties of osteogenesis, osteoinduction and osteoconduction [4]. However, its use has become limited due to the difficulty in obtaining, restricted bone quantity, possibility of infections and morbidity of the donor area $[1,5]$.

In an attempt to replace the autogenous graft, alloplastic biomaterials have been a viable alternative due to the possibility of optimizing their physical characteristics, obtaining materials with satisfactory osteoconductive properties [3,6]. Among alloplastics, biphasic calcium phosphate (BCP), hydroxyapatite $(\mathrm{HA})$ associated with $\beta$-tricalcium phosphate ( $\beta$-TCP) are materials similar to the inorganic phase of bone tissue, providing excellent biocompatibility, atoxicity, does not induce immunogenicity, biodegradability and mechanical resistance which makes the biomaterial favorable to new bone formation $[7,8]$.

With the knowledge that biomaterials do not possess the properties of osteogenesis, osteoinduction and osteoconduction, which are fundamental for the regenerative process, researchers have made an association between them in order 
to obtain synergistic effects. Thus, many studies have analyzed the incorporation of biomaterials into three-dimensional matrices, such as natural biopolymers, most commonly fibrin sealants [9-11].

In the last decades, the heterologous fibrin sealant has shown efficacy in the bone repair process due to its three-dimensional structure, which allows anchoring of cells and growth factors, helping in cell proliferation and differentiation. Thus, in recent years, its name has been changed to fibrin biopolymer (FBP), due to its vast possibility of clinical application [12-14].

In the search for the evolution of diverse regenerative techniques, new resources and treatment options have made it possible to achieve results close to the bone remodeling process. Thus, guided bone regeneration has become an effective technique in the treatment of bone defects. It is based on the concept of osteopromotion, with the objective of physically protecting the surgical site through membranes in order to prevent the invasion of cells coming from connective and epithelial tissue in situ, enabling bone neoformation $[15,16]$.

In addition, alternative non-invasive methods have been used in tissue regeneration, such as laser photobiomodulation therapy (PBMT) [17-19]. In the bone repair process, this therapy is known to exert analgesic anti-inflammatory effects, in addition to accelerating the regeneration process by providing cell proliferation and differentiation [20-23].

Thus, due to the low cost compared to international products, ease of acquisition, biocompatibility, among other desirable properties that fibrin biopolymer and biphasic calcium phosphate present, coupled with the lack of studies that correlate these biomaterials with photobiomodulation therapy to laser, research in the field of 
guided bone regeneration is necessary due to the numerous grafting procedures that are carried out involving bone losses.

Therefore, the aim of the present study was to evaluate the effects of laser photobiomodulation therapy (PBMT) on the bone regeneration process guided in bone defects in rats' calvaria filled with biphasic calcium phosphate incorporated into the heterologous fibrin biopolymer.

\section{MATERIAL AND METHODS}

\section{Alloplastic Biomaterial}

The biomaterial used in the present study was the Genphos $\mathrm{XP}^{\circledR}$ (Baumer S.A., Mogi Mirim, SP, Brazil, Ministry of Health Registry No. 10345500076). It is a biphasic bioceramic composed of hydroxyapatite and $\beta$-tricalcium phosphate in the proportion of $70 \%-30 \%$ with granulometry between 0.50 to $0.75 \mathrm{~mm}$ and packed in $0.7 \mathrm{~g}$ packaging. It presents an irregular surface with several concavities and cracks, in addition to macros and micropores of different diameters with an estimated resorption time between 7 to 9 months.

Genphos $\mathrm{XP}^{\circledR}$ is used in implant dentistry, maxillofacial and bone surgery procedures. Previous studies report osteogenic potential when implemented in bone defects $[24,25]$ and can be considered a safe alternative to autologous grafting. 


\section{Fibrin biopolymer}

The fibrin biopolymer was kindly provided by the Center for the Study of Venoms and Venomous Animals - CEVAP of the São Paulo State University "Júlio de Mesquita Filho", registration $\mathrm{n}^{\circ}$ BR1020140114327 and BR1020140114360. The package available for clinical research consists of three solutions, packaged separately and kept at -18 to $-22^{\circ} \mathrm{C}$ :

- Fraction 1: thrombin-like or gyroxin purified from the poison of Crotalus durissus terrificus, $0.4 \mathrm{~mL}$;

- Diluent: calcium chloride, $0.6 \mathrm{~mL}$.

- Fraction 2: fibrinogen, cryoprecipitate derived from the blood of buffalo Bubalus bubalis), $1 \mathrm{~mL}$;

The proportion used (1: 1: 2) was in accordance with the manufacturer's recommendations and the amount readjusted through a pilot study.

\section{Preparation of the Biopolymer}

The solutions were thawed and kept at room temperature between $15-30^{\circ} \mathrm{C}$, and then homogenized. In BFMG and BFMLG animals, $10 \mu \mathrm{L}$ of fraction 1 and $10 \mu \mathrm{L}$ of diluent were added to $0.015 \mathrm{~g}$ of biomaterial, and then the mixture was incorporated to $20 \mu \mathrm{L}$ of fraction 2 for polymerization to occur. 


\section{Guided Bone Regeneration (GBR)}

The membrane used to perform the GBR was the GenDerm ${ }^{\circledR}$ (Baumer S.A., Mogi Mirim, SP, Brazil, with registration number 10345500069), derived from the bovine bone cortex with flexible and resorbable characteristics.

Native bone collagen is obtained in a standardized process of removing the mineral portion and lamination of bovine cortical bone. Its manufacturing process provides a porous, acellular, biocompatible, non-antigenic, non-pyrogenic membrane with a high degree of purity, free from contamination with heavy metals and other proteins.

The choice to use the GenDerm ${ }^{\circledR}$ membrane is supported in the literature with its use in bone defects such as calvaria and tibia of rats to prevent the invasion of soft tissues at the injury site and assist in regeneration [26-28].

For this experiment, the membrane was used with dimensions of $20 \times 20 \mathrm{~mm}$ (height / width), with size adaptation according to the defect made in the present study.

\section{Experimental Design}

Thirty male Wistar rats (Rattus norvegicus), adult (90 days old), weighing approximately 250 grams, provided by the Central Bioterium of the University of Marilia after approval by the Animal Use Ethics Committee (CEUA) of the University of Marília under protocol 04/2018, number CIAEP - 01.0218.2014, of June 28, 2018 (annex 1) were used. 
The animals were kept in conventional cages containing 04 animals each, under artificial lighting controlled by a timer, a 12-hour light / dark cycle, an exhaust fan and air conditioning to maintain an average temperature around $22^{\circ} \mathrm{C}$.

The animals were randomly separated into three groups: BMG $(n=10)$, defects filled with biomaterial and covered by a membrane; BFMG $(n=10)$, defects filled with the association of biomaterial and fibrin biopolymer, covered by a membrane; BFMLG $(n=10)$, defects filled with the association of biomaterial and fibrin biopolymer, covered by a membrane and biostimulated with laser (Figure 1). 


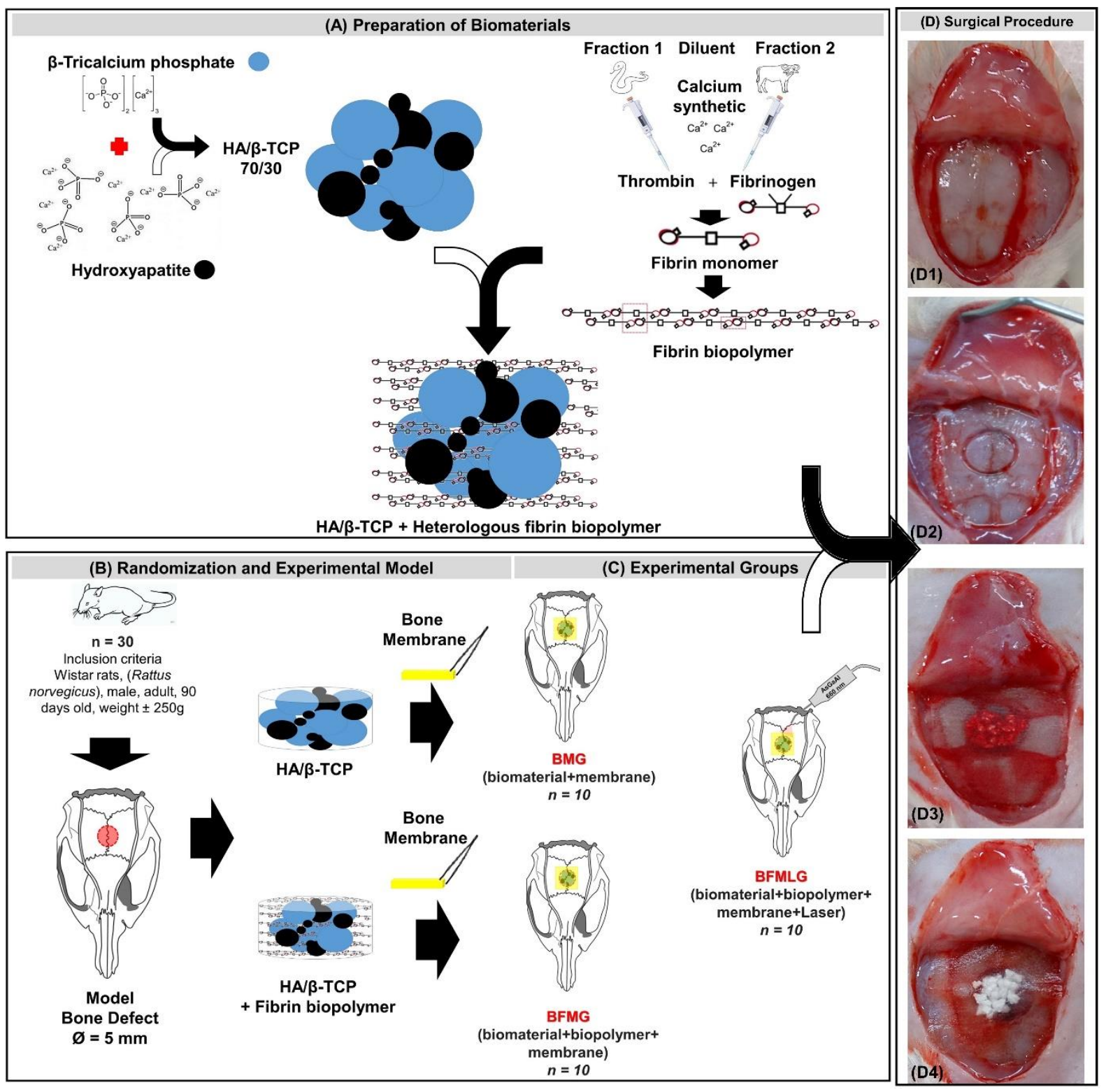

Figure 1 - Schematic drawing of the experimental design. A) Preparation of biomaterials: Alloplastic hydroxyapatite and beta beta triphosphate in the ratio of 70:30 (HA / $\beta$-TCP 70 / 30). Heterologous fibrin biopolymer - Fraction 1 (thrombin-like or gyroxin), diluent (synthetic calcium), fraction 2 (buffalo fibrinogen). HA / $\beta$-TCP association and heterologous fibrin biopolymer. B) Randomization and experimental model: 30 male rats, Rattus norvegicus, Wistar, adults, 90 days old, weighing approximately 250 grams. Experimental model $-5 \mathrm{~mm}$ bone defect in the center of the parietal bones. C) Experimental groups: BMG $(n=10)$, defects filled with HA / $\beta$-TCP and covered by a membrane; BFMG $(n=10)$, defects filled with the association of HA / $\beta$-TCP and fibrin biopolymer, covered by a membrane; BFMLG $(n=10)$, defects filled with the association of HA / $\beta$-TCP and fibrin biopolymer, covered by a membrane and biostimulated with laser. D) Surgical procedure: D1) Parietal exposure. D2) Defect in the center of the parietal bones. D3) Defect filled with HA / $\beta$-TCP and heterologous fibrin biopolymer. D4) Bone defect filled with HA / $\beta$-TCP and heterologous fibrin biopolymer covered by a membrane derived from the bovine bone cortex. 


\section{Surgical Procedure}

The surgery was performed at the Central Bioterium of the University of Marília (Unimar) where the rats were previously weighed and then anesthetized with intramuscular injection of tiletamine hydrochloride associated with zolazepam $10 \mathrm{mg} /$ kg IM, (Telazol ${ }^{\circledR}$; Fort Dodge Laboratories, USA ).

Trichotomy was performed in the frontoparietal region and disinfection with $10 \%$ polyvidone-iodine (Povidine ${ }^{\circledR}$, Vic Pharma, Brazil). Next, a semilunar incision of four centimeters was made with a No. 15 carbon steel scalpel blade $\left(E_{m b r a m a x}{ }^{\circledR}, \mathrm{SP}\right.$, Brazil) in the integument, and the periosteum was carefully detached with the aid of the syndesmotome and folded together with the other tissues, exposing the external surface of the parietal bones. A $5.0 \mathrm{~mm}$ diameter circular osteotomy was performed in the center of the parietal bones with the aid of a trephine drill (Neodent $\left.{ }^{\circledR}, \mathrm{PR}, \mathrm{Brazil}\right)$ adapted to the $500 \mathrm{Kavo}^{\circledR}$ electric contra-angle (KaVo ${ }^{\circledR}$ Dental Excelence, SC, Brazil) coupled to an electric micromotor (Kavo ${ }^{\circledR}$ Dental Excelence, SC, Brazil), at low speed (1500 rpm), under constant and abundant sterile saline irrigation (0.9\% saline).

In the BMG animals, the defects were filled with $0.015 \mathrm{~g}$ of biomaterial mixed with blood clot. In the animals of the BFMG and BFMLG groups, the defects were filled with the association of $0.015 \mathrm{~g}$ of the biomaterial and $40 \mu \mathrm{L}$ of the polymerized fibrin biopolymer (Figure 1). Next, the membrane hydrated in $0.9 \%$ saline solution was carefully implanted over the defects, exceeding the limits of the edges by $2.5 \mathrm{~mm}$. The periosteum and integument were repositioned and sutured with 5-0 nylon (Mononylon ${ }^{\circledR}$, Somerville S.A) and 4-0 silk (Ethicon ${ }^{\circledR}$ Johnson \& Johnson Company), respectively. The region was carefully cleaned with $2 \%$ chlorhexidine (Riohex ${ }^{\circledR}$ Farmacêutica Rioquímica Ltda, Brazil). 
Immediately after the surgical procedure, the animals received intramuscular injections in a single dose of $0.2 \mathrm{ml} / \mathrm{kg}$ enrofloxacin antibiotic (Flotril ${ }^{\circledR} 2.5 \%$, ScheringPlow, Rio de Janeiro, Brazil) and dipyrone $0.06 \mathrm{ml} / \mathrm{kg}$ (Analgex $\mathrm{V}^{\circledR}$ Agener União, São Paulo, Brazil), remaining with $200 \mathrm{mg} / \mathrm{Kg}$ paracetamol (Medley ${ }^{\circledR}, \mathrm{SP}$, Brazil), dissolved in the water available in the drinking fountain until the euthanasia period.

\section{Laser Photobiomodulation Therapy}

Immediately after the surgical procedure, the GBFML animals were submitted to photobiomodulation therapy (Ibramed Laserpulse ${ }^{\circledR}$, Amparo, SP, Brazil) until the end of the experiment (Figure 2), 14 and 42 days [22,23], using the following protocol:

\begin{tabular}{lc}
\hline Parameter & Unit/Description \\
\hline Output power & $30 \mathrm{~mW}$ \\
Wavelength & $830 \mathrm{~nm}$ \\
Power density & $258.6 \mathrm{~mW} / \mathrm{cm}^{2}$ \\
Energy density & $6.2 \mathrm{~J} / \mathrm{cm}^{2}$ \\
Beam area & $0.116 \mathrm{~cm}^{2}$ \\
Total power & $2.9 \mathrm{~J}$ \\
Beam type & Positioned perpendicular to the skull \\
Emission mode & Continuous \\
Form of application & Four points around the surgical area \\
Irradiation duration & 24 seconds per point \\
Total time of each & 96 seconds \\
application & Immediately after surgery and three times a \\
Treatment time & week until euthanasia. \\
\end{tabular}




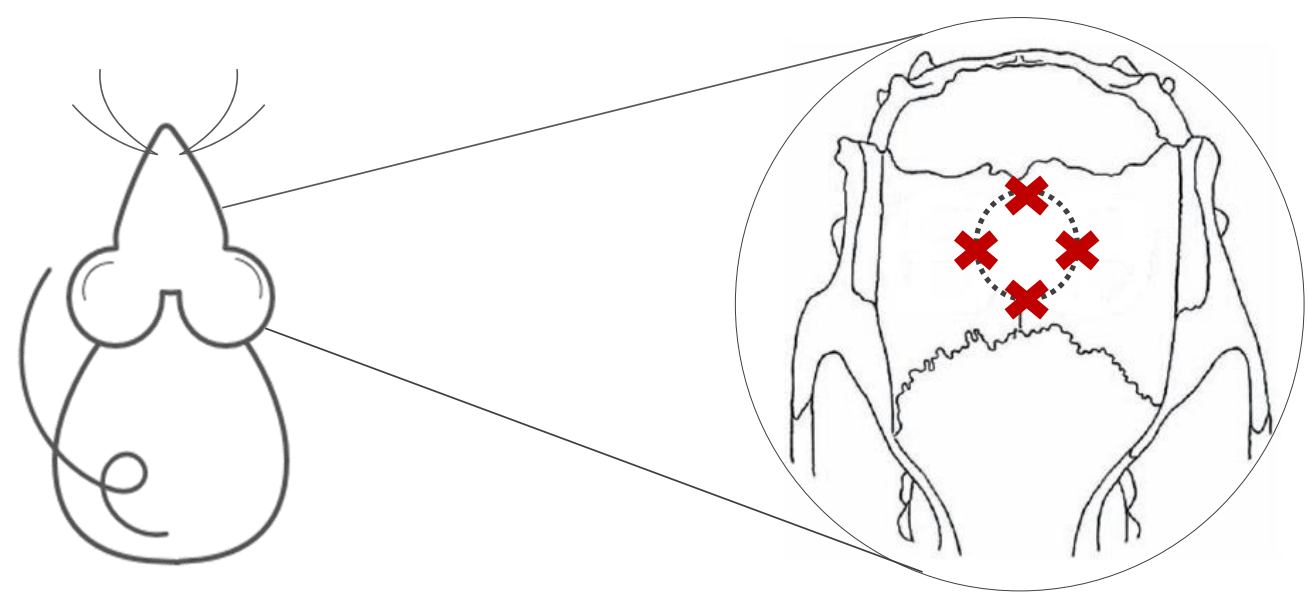

Figure 2 - Demonstration of the four points of laser application at the defect margins.

\section{Sampling and Histological Procedures}

After 14 and 42 days, five animals in each group were subjected to excessive doses of anesthetic, 2.5\% sodium thiopental (Thiopentax ${ }^{\circledR}$, Cristália, Produtos Químicos Farmacêuticos Ltda, SP, Brazil) intraperitoneally and intramuscular injection of $1 \%$ lidocaine hydrochloride (Blau ${ }^{\circledR}$ Farmacêutica SA, SP, Brazil).

The caps of each specimen were removed preserving the supraperiosteal soft tissues and fixed in a $10 \%$ buffered formalin solution and later were destined for computerized microtomography analysis.

\section{Micro-CT}

After fixing the bone fragments, the pieces were subjected to an X-ray beam scan in the SkyScan 1174v2 computerized microtomograph (Bruker-microCT ${ }^{\circledR}$, Kontich, Belgium) of the Discipline of Endodontics, Bauru School of Dentistry, FOBUSP. The X-ray beam sources (Cone-Beam) were operated at $50 \mathrm{kV}, 800 \mathrm{uA}$, using a 
$\mathrm{Cu}+\mathrm{Al}$ filter and rotated through $360^{\circ}$, with a 0.5 rotation step and an isotropic resolution of $19.6 \mu \mathrm{m}$.

The images were reconstructed using the NReconTM v.1.6.8.0 program (SkyScan ${ }^{\circledR}, 2011$, Bruker-microCT), with the same reconstruction parameters for all samples. Next, the reconstructed images were realigned with the DataViewer ${ }^{\circledR}$ 1.4.4.0 software resulting in two-dimensional transaxial and sagittal images with 16-bit gray scale resolution.

\section{Histotechnical Processing}

The pieces were then washed in running water for 24 hours and subjected to demineralization in 10\% EDTA (4.13\% tritiplex ${ }^{\circledR}$ III, Merck KGaA, Hessen, Germany and $0.44 \%$ sodium hydroxide ${ }^{\circledR}$, Labsynth, SP, Brazil), with weekly changes of the solution for a period of approximately six weeks, carried out at the Anatomy Laboratory of Bauru School of Dentistry, University of São Paulo (FOB-USP).

Next, the bone fragments collected were subjected to standard histological processing and included in a HistosecTM (Merck KGaA ${ }^{\circledR}$, Darmstadt, Germany) at the Histology Laboratory of the University of Marília (Unimar). Semi-serial coronal slices with $5 \mu \mathrm{m}$ thicknesses were made prioritizing the center of the defect and stained with hematoxylin-eosin, Masson's trichrome and picrosirius-red.

The defect images were obtained using the Leica DFC 310FX high resolution digital camera (Leica ${ }^{\circledR}$, Microsystems, Wetzlar, Germany) connected to the Leica DM IRBE inverted laser microscope and LAS 4.0.0 capture system (Leica ${ }^{\circledR}$, Microsystems, Heerbrugg, Switzerland ) at the Anatomy Laboratory of FOB-USP. 
Each type of fiber by color was analyzed using the Axio Vision Rel. 4.8 Ink image software (Carl Zeiss ${ }^{\circledR}$ Microlmaging $\mathrm{GmbH}$, Jena, Germany). The interlaced bone was recognized for its random and unorganized fibrillar pattern, usually with polarization colors ranging from red / orange to light green / yellow, depending on the width of the fiber.

\section{Histomorphological and Histomorphometric Analyses}

For the histomorphological description of the areas of the bone defect in all specimens, the central region and the border were considered to evaluate the incorporation of the biomaterial in the recipient bed, the formation of granulation tissue, infiltration of inflammatory and blood cells and tissue formation primary bone (immature bone) and secondary bone (lamellar bone - bone maturation). For this, four semi-serial sections of the surgical bed were evaluated by slide for each specimen.

For histomorphometric analysis, blades stained with Hematoxylin and Eosin were observed under the Olympus BX50 light microscope (Olympus ${ }^{\circledR}$ Corporation, Tokyo, Japan) and the photographs captured in $4 \mathrm{x}$ lens with the digital camera attached (Olympus ${ }^{\circledR}$ DP 71, Tokyo, Japan) at the Anatomy Laboratory of FOB-USP.

Quantitative analysis was performed on the computer (Pentium ${ }^{\circledR}$ Core 2 Duo processor; Intel Corporation, Santa Clara, CA, USA) using the Axio Vision Rel. 4.8 Ink image software program (Carl Zeiss ${ }^{\circledR}$ Carl Zeiss Microlmaging $\mathrm{GmbH}$, Jena, Germany) at Anatomy Laboratory of FOB-USP.

From the semi-serial sections obtained, two more central sections of the defect were captured with a distance of $300 \mu \mathrm{m}$ between them. The total area of the removed bone block or total area of the defect (TA) and the area of new bone formation (ANB) 
of each defect were determined. The percentage of newly formed bone tissue (PNB) was calculated by the following relationship: $\mathrm{P}_{\mathrm{NB}}=\mathrm{A}_{\mathrm{NB}} \times 100 /$ TA [23].

\section{Statistical Analysis}

Statistical analysis was performed on the computer using the GraphPad Prism 8 Program (GraphPad ${ }^{\odot}$ Software 2018, San Diego, CA, USA).

To analyze the influence of time on the percentage of new bone formation within each experimental group, an "unpaired t test" was used and, for comparative analysis of the percentage of new bone formed by comparing the groups within the same experimental period, ANOVA for independent samples and the "post hoc" Tukey's test.

For all analyses, $p$ values $<0.05$ were considered statistically significant $(n=5$ for each period and group). Bartlett's test was used as a test of data normality.

\section{RESULTS}

\section{Microtomographic Analysis}

Microtomographic images of all experimental groups revealed a gradual increase in radiopacity in a time-dependent manner and consistent with the centripetal bone growth, starting from the defect margins, evidenced by the hypodense areas of the newly formed tissue (see Figure 3 A2-B2).

At 14 days, all bone defects were filled with radiopaque constituents referring to the particles of the biomaterial, without overlapping beyond the limits of the defect and 
permeated by hypodense areas of newly formed bone close to the defect edge (Figure 3 A1-A2).

At 42 days, there was a progressive increase in density, by shades of gray, represented by the new bone tissue, forming isodense areas, but without complete closure of the wound. At the end of the experimental period, the surgical defects were almost completely filled with particles, areas with no density shown in black, and areas remodeled at the margins, most evident in the BFMLG group (Figure 3 B1-B2).

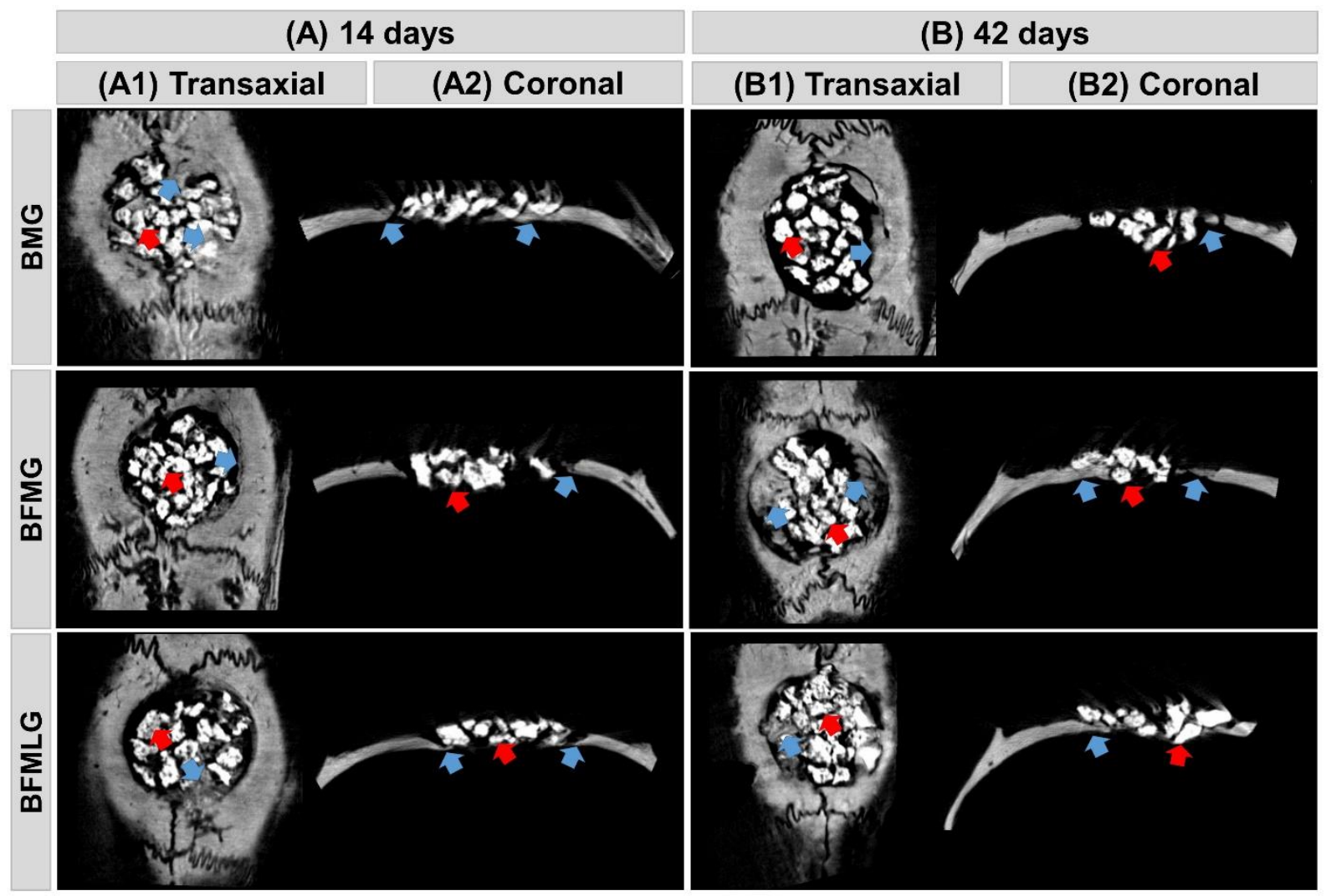

Figure 3 - A-B) Two-dimensional (2D) reconstructions of microtomographic images, in transaxial (A1B1) and coronal (A2-B2) sections of bone defects in the calvary of rats at 14 and 42 days, respectively. BMG - defects filled with biomaterial and covered by a membrane; BFMG - defects filled with the association of biomaterial and fibrin biopolymer, covered by a membrane; BFMLG - defects filled with the association of biomaterial and fibrin biopolymer, covered by a membrane and biostimulated with laser. Blue arrow - new bone tissue; red arrow - particle of biomaterial. 


\section{Histomorphological Analysis}

At 14 days, it was observed, in all experimental groups, well-defined bony edges with a flat chamfered shape and new immature bone tissue overlapping the dura mater. The entire surgical area was filled with biomaterial particles of various sizes surrounded by reactive connective tissue with the presence of inflammatory infiltrate and newly formed blood vessels (Figure 4A and Figure 5C).

In all specimens, at 42 days, there was a slight increase in the formed bone tissue, with lamellar structure, surrounding the surfaces of the particles. The defects were interposed by a thin fibrous connective tissue with a reduction in the mononuclear inflammatory infiltrate and accompanied by a slight proliferation of blood capillaries. The collagen fibers were arranged circumferentially and parallel to the particles, forming thick concentric layers. The membranes were not evident in all specimens, but in some there were remnants on the surgical bed (Figures 4B and 5D). 

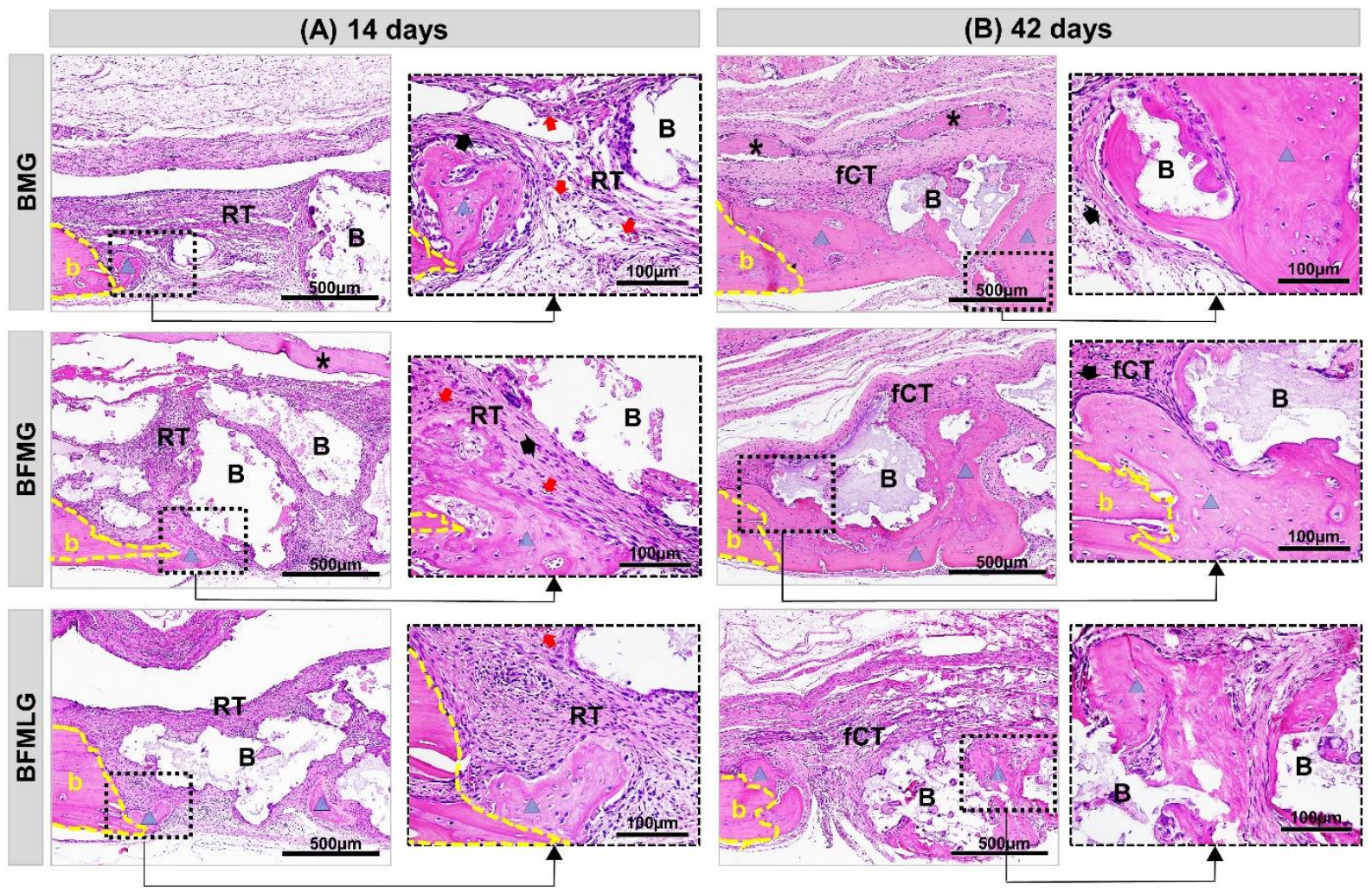

Figure 4 - A-B) Histological images of the evolution of defects in rat skull caps in the experimental periods of 14 and 42 days, respectively. BMG - defects filled with HA / $\beta$-TCP covered by a bovine biological membrane; GBFM defects filled with HA / $\beta$-TCP and heterologous fibrin biopolymer covered with bovine biological membrane; BFMLG defects filled with HA / $\beta$-TCP and heterologous fibrin biopolymer covered with bovine biological membrane and biostimulated with laser (PBMT). Bone border (b), reactive connective tissue (RT), biomaterial particles (B), bovine biological membrane (asterisk), new bone tissue (blue triangle), fibrous connective tissue ( $\mathrm{fCT}$ ), collagen fibers (black arrow), blood vessel cells (red arrow). H.E. Original 10x magnification; bar $=500 \mu \mathrm{m}$ and inserts, enlarged 40x images ; bar $=100 \mu \mathrm{m})$. 


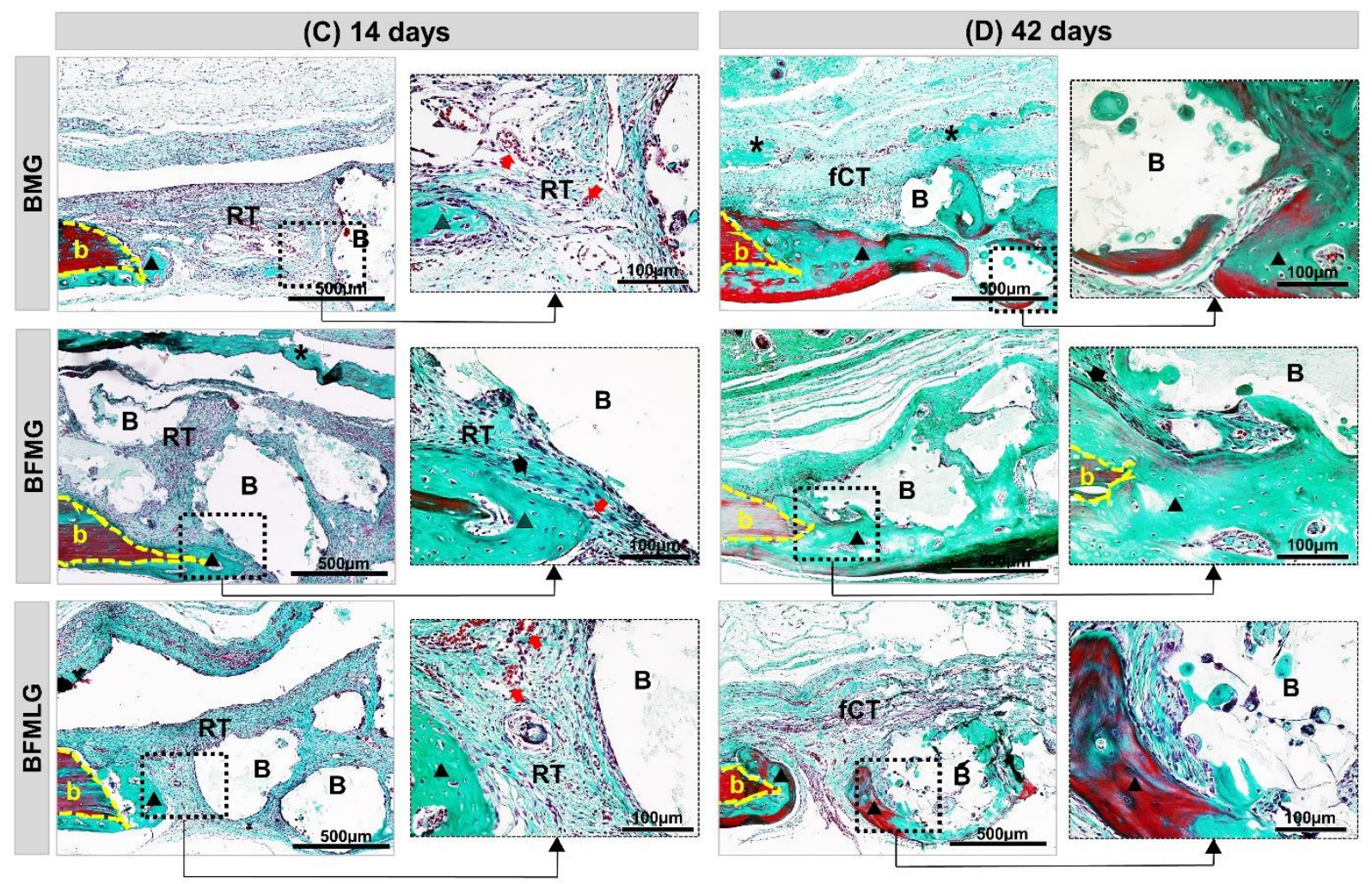

Figure 4 - C-D) Histological images of the evolution of defects in rats' skull caps in the experimental periods of 14 and 42 days, respectively. BMG - defects filled with HA / $\beta$-TCP covered by a bovine biological membrane; BFMG defects filled with HA / $\beta$-TCP and heterologous fibrin biopolymer covered with bovine biological membrane; BFMLG defects filled with HA / $\beta$-TCP and heterologous fibrin biopolymer covered with bovine biological membrane and biostimulated with laser (PBMT). Bone border (b), reactive connective tissue (TR), biomaterial particles (B), bovine biological membrane (asterisk), new bone tissue (black triangle), fibrous connective tissue (TCf), collagen fibers (black arrow), blood vessel cells (red arrow). Masson's trichrome. Original 10x magnification; bar $=500 \mu \mathrm{m}$ and inserts, 40x enlarged images; bar $=100 \mu \mathrm{m}$ ).

\section{Histomorphometric Analysis}

In the percentage of new bone formation, a significant difference was observed in all experimental groups when comparing the two periods of experimentation (14 and 42 days; Figure 6$)$. 

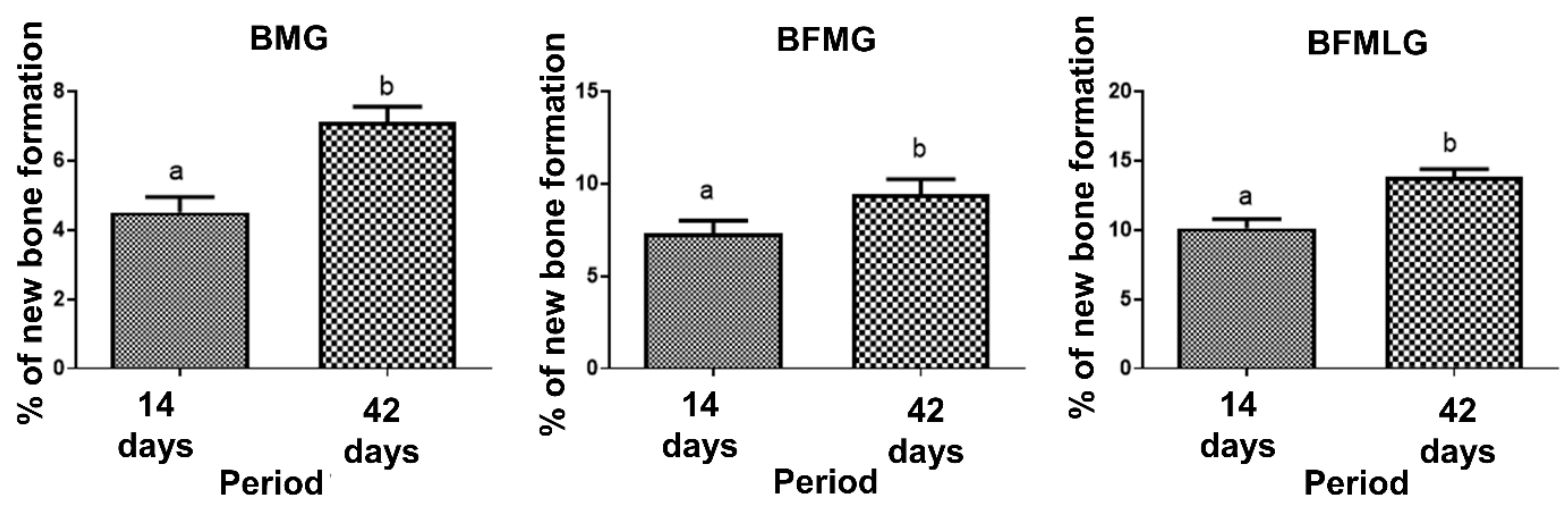

Figure 6 - Percentage of new bone formation in each group (BMG, BFMG and BFMLG) in the two experimental periods (14 and 42 days). Different lowercase letters indicate significant difference. Values defined as mean \pm standard deviation $(p<0.05)$, unpaired $t$ test.

In the comparative analysis between the groups, in relation to the percentage of new bone formed, in each experimental period (14 and 42 days), a significant difference was observed between all groups (Figure 7 and table $1 ; p<0.05$ ).

14 days

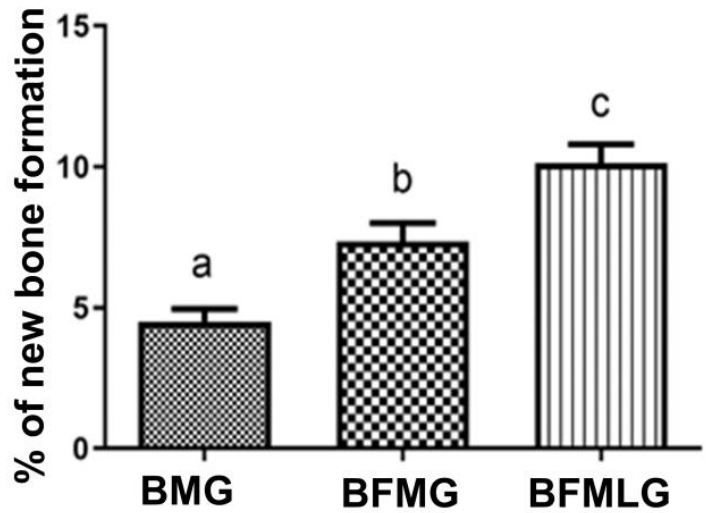

42 days

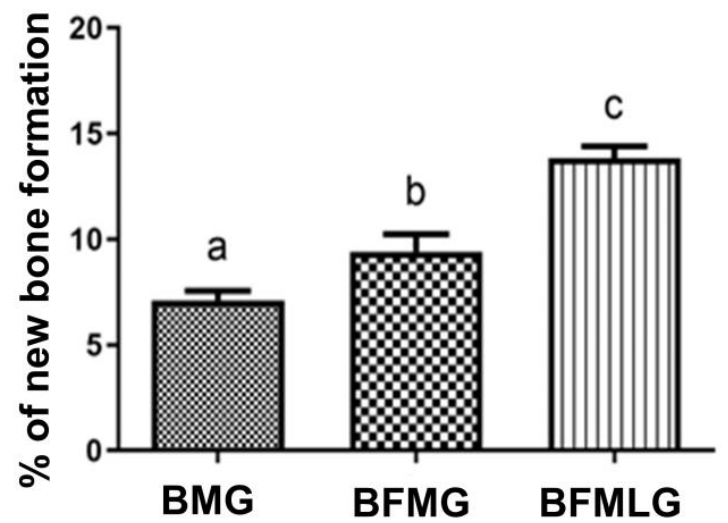

Figure 7 - Percentage of new bone formation in each group (BMG, BFMG and BFMLG) in the two experimental periods (14 and 42 days). Different lowercase letters indicate a significant difference. Values defined as mean \pm standard deviation $(p<0.05)$, ANOVA test for independent samples and the "post hoc" Tukey`s test $(p<0.0001)$. 
Table 1 - Percentage of new bone formation in each group (BMG, BFMG and BFMLG) in the two experimental periods (14 and 42 days).

\begin{tabular}{c|c|c|c} 
& 14 DAYS & 42 DAYS & $p$ value \\
\hline BMG & $4,51 \pm 0,44^{\mathrm{a} A}$ & $7,11 \pm 0,44^{\mathrm{b}} \mathrm{A}$ & $\mathrm{p}<0,0001$ \\
BMFG & $7,35 \pm 0,66^{\mathrm{a}} \mathrm{B}$ & $9,41 \pm 0,84^{\mathrm{b}} \mathrm{B}$ & $\mathrm{p}=0,0026$ \\
BMFLG & $10,12 \pm 0,67^{\mathrm{a}} \mathrm{C}$ & $13,85 \pm 0,54^{\mathrm{b}} \mathrm{C}$ & $\mathrm{p}<0,0001$
\end{tabular}

Different lowercase letters (line) indicate a significant difference in each group in the 2 periods (unpaired $t$ test). Different capital letters (column) indicate a significant difference in the same period between groups (ANOVA and Tukey). Values defined as mean \pm standard deviation $(p<0.05)$.

\section{Analysis of Birefringence of Collagen Fibers}

Through the polarization of the collagen fibers stained by Picrosirius-red, it was possible to qualitatively analyze the level of bone maturation in the selected periods considering the quantity and thickness of the aligned filaments.

Thus, in the present experiment, the yellow-green birefringence color indicates thicker collagen fibers, lamellar bone, while the orange-red color indicates thin collagen fibers, immature bone, recognized for its random and disorganized fibrillar pattern.

In the initial period of bone deposition, at 14 days, intense collagen synthesis was observed in all experimental groups, extending from the edges towards the center of the surgical defect, surrounding the biomaterial particles that remained on a dark background (Figure 8 - see asterisk). In the BFMLG group, regions in a more advanced stage of maturation were noted, with collagen fibers transitioning to yellowish-green birefringence more centrally (Figure 8 - see white arrow).

At 42 days, all specimens showed predominantly red birefringence and greenish locus. However, the biostimulated animals, the BFMLG, showed a higher intensity of 
birefringence of bright green collagen, indicating better organization of type I collagen bundles (Figure 8).

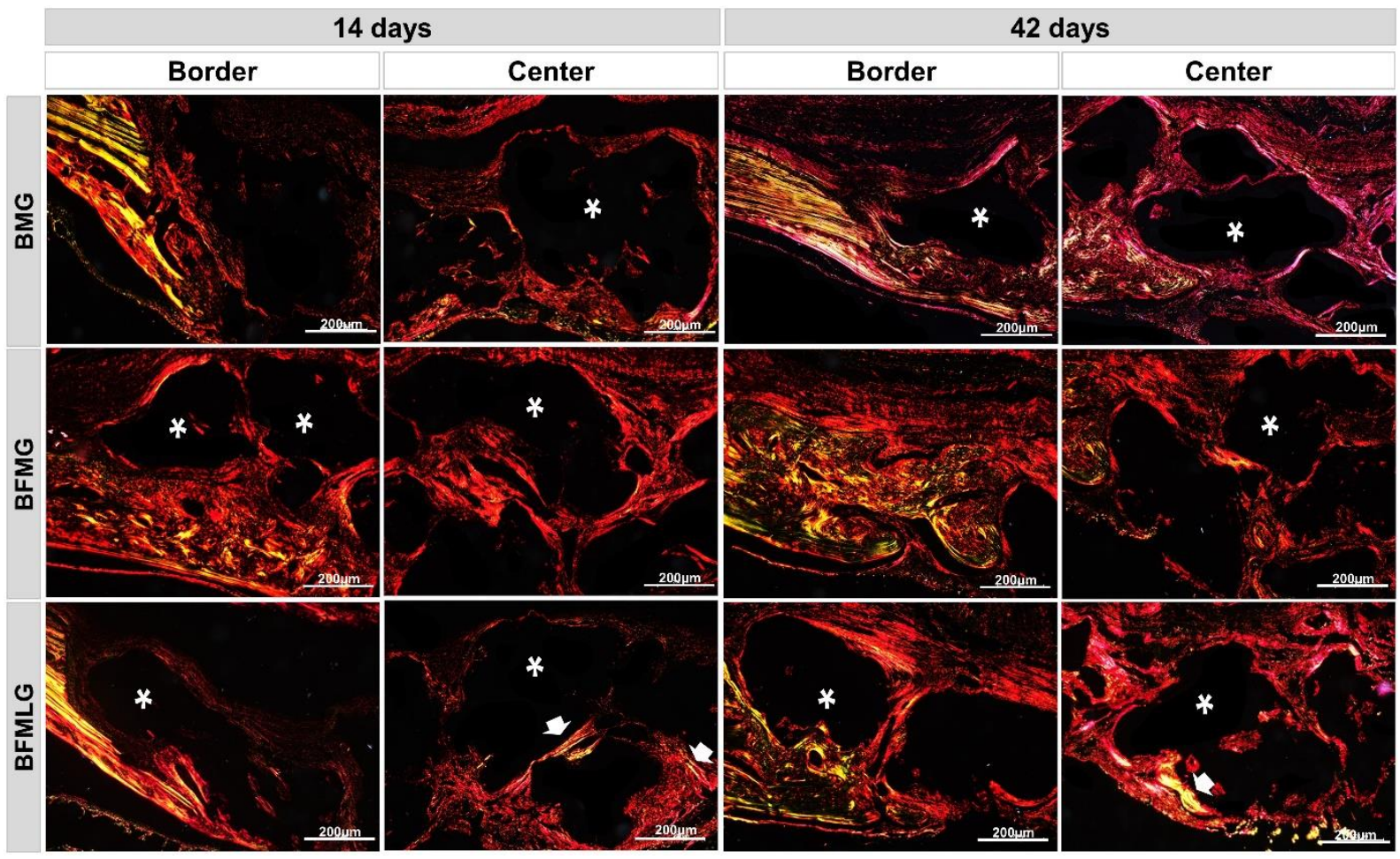

Figure 8 - Histological sections of the border and center of the bone defect of rat calvaria stained by Picrosirius-red under polarized light at 14 and 42 days. GBM - defects filled with HA / $\beta$-TCP covered by a bovine biological membrane; BFMG defects filled with HA / $\beta$-TCP and heterologous fibrin biopolymer covered with bovine biological membrane; BFMLG defects filled with HA / $\beta$-TCP and heterologous fibrin biopolymer covered with bovine biological membrane and biostimulated with laser (PBMT). RGB greenyellow-red colors. Mature bone - yellowish-green fibers (white arrow); Immature bone - orange-red; particles of the biomaterial (dark background - asterisk). Original $10 \times$ magnification, $200 \mu \mathrm{m}$ scale bar.

\section{DISCUSSION}

Due to the need for a treatment for the recovery of bone tissue when affected by critical size injuries, several techniques and materials have been investigated to facilitate and improve regeneration [5,29]. In light of this, the results of the present study showed that laser photobiomodulation therapy associated with biphasic calcium phosphate and fibrin biopolymer contributed to bone regeneration guided by defects in the calvaria of rats. 
Previous studies showed that the laser used, AIGaAs with a wavelength of 830 $\mathrm{nm}$, presented satisfactory performance since it is able to penetrate deeper tissues such as bone, accelerating the tissue repair process [17-19,22]. However, due to the numerous dosimetry protocols, there is still no consensus in the literature as to the ideal application protocol [30].

The wavelength used in the present study is within the therapeutic window, 820$840 \mathrm{~nm}$, because in this spectral range, the more superficial chromophores of the intercalated layers have low selectivity, with greater penetration and consequently greater absorption by the chromophores, cytochrome-c oxidase present in the tissue bone [30-32].

In the microtomographic evaluation, it was possible to observe a progressive increase in new tissue formed, more evident in the BFMLG with remodeling at the margin of the defect at the end of 42 days. This can be attributed to the exponential action of the laser throughout the experimental period, in the initial phase, 14 days, accelerating the inflammatory process, allowing the deposition of osteoid matrix and in the late phase, 42 days, increased expression of osteoblastic differentiation markers ALP, BMP-4 and RUNX2 [33].

In addition, all groups had areas with no density, black, until the end of the experiment, indicating that there was no complete bone regeneration due to the fact that it is a critical size lesion according to Gosain et al. [34].

Histologically, in the initial stages, 14 days, the presence of reactive connective tissue with inflammatory infiltrate and newly formed blood vessels was noted in all experimental groups. This inflammation can be explained due to the fact that the lesion causes changes in the immunogenic characteristics of the cells with the implantation 
of biomaterials as a protective response, being of great importance the communication of osteogenic cells with inflammatory cells in the initial remodeling process [35-37].

At 42 days, it is possible to notice a slight tissue growth with controlled inflammatory response and collagen fibers arranged in concentric layers, indicating secondary bone tissue. It is suggested that this picture is related to the biocompatibility and osteoconductive capacity of biomaterials. This is because biphasic bioceramics have hydroxyapatite in their composition which is similar to the inorganic phase of bone tissue, in addition to presenting macropores of different sizes that favor cell migration and restocking $[24,38,39]$.

Allied to biphasic ceramics, the fibrin biopolymer (FBP) acting as a scaffold facilitated the insertion of the graft, and due to its three-dimensional structure, it promoted greater stability at the defect site $[14,40,41]$. Such findings are in line with studies that used FBP for the same purpose, obtaining favorable results in tissue regeneration $[12,42]$.

The bovine cortical bone membrane was used in all groups in order to act as a physical barrier, preventing non-osteogenic cells from invading the surgical area $[27,43,44]$. Until the end of the experiment, it was possible to observe remnants of the membrane.

In the histomorphometric analysis, there was a significant difference in all groups, which showed bone growth from 14 to 42 days, confirmed qualitatively by microtomographic analysis. Comparing groups within the same experimental period, the BFMLG showed greater bone formation in both periods $(10.12 \pm 0.67$ and $13.85 \pm$ 0.54), followed by BFMG (7.35 \pm 0.66 and $9.41 \pm 0.84)$ and BMG (4.51 \pm 0.44 and 7.11 $\pm 0.44)$. This can be attributed to factors such as the laser irradiation protocol used 
which has been tested in our research group showing positive effects on tissue regeneration $[21-23,45]$.

In addition, the synergistic effect of fibrin biopolymer with bioceramics can be suggested for this result, presenting a more resistant structure, favoring its use in regeneration procedures. It is important to show that, although GenPhos $\mathrm{XP}^{\circledR}$ is already commercialized and used widely in dentistry, no studies were found involving this biomaterial to the fibrin biopolymer, listing the present research as a pioneer in the process of guided bone regeneration in the skull cap of rats.

The registration of collagen fibers can be considered an important indicator of bone formation, with type I collagen being the main component of the organic matrix of the bone, responsible for the flexibility of the bone $[46,47]$.

According to our qualitative birefringence data, in the first period, it was possible to observe an intense collagen synthesis in all groups. Such data may be due to laser biostimulation in the differentiation and proliferation of fibroblastic cells. The BFMLG stood out from the others for presenting regions in an advanced stage of maturation with a transition from the birefringence color of the yellowish-green collagen fibers [23].

At 42 days, the BFMLG was also the group that showed the best organized pattern of bundles of type I collagen, evidenced in bright green color, characterizing the lamellar bone. It is suggested that laser biostimulation may have contributed to the parallel arrangement and thickening of collagen fibers, providing the deposit of inorganic salts for the formation of mature bone [48].

For prospective works, the use of other innovative therapies are suggested that assist bone growth such as low-intensity pulsed ultrasound (LIPUS) [49] and LED phototherapy [50]. In addition, research on fibrin biopolymer and bioceramics associated with the same laser photobiomodulation therapy protocol in other 
anatomical regions such as long bones is believed to be of fundamental importance [51].

\section{CONCLUSION}

It is concluded that laser photobiomodulation therapy, being a non-invasive and easily accessible procedure, showed positive effects capable of improving and accelerating the guided bone regeneration process when associated with biphasic calcium phosphate and fibrin biopolymer.

\section{REFERENCES}

1. Janicki $P$, Schmidmaier $G$. What should be the characteristics of the ideal bone graft substitute? Combining scaffolds with growth factors and/or stem cells. Injury. Elsevier Ltd; 2011;42:S77-81.

2. Majidinia M, Sadeghpour A, Yousefi B. The roles of signaling pathways in bone repair and regeneration. J Cell Physiol. 2018;233:2937-48.

3. Dimitriou R, Mataliotakis GI, Calori GM, Giannoudis P V. The role of barrier membranes for guided bone regeneration and restoration of large bone defects: Current experimental and clinical evidence. BMC Med. 2012;10:81.

4. Cypher TJ, Grossman JP. Biological principles of bone graft healing. J Foot Ankle Surg. American College of Foot and Ankle Surgeons; 1996;35:413-7.

5. Rogers GF, Greene AK. Autogenous bone graft: Basic science and clinical implications. J Craniofac Surg. 2012;23:323-7.

6. Giannoudis P V., Dinopoulos H, Tsiridis E. Bone substitutes: an update. Injury. 2005;36 Suppl 3:20-7.

7. Dorozhkin S V. Bioceramics of calcium orthophosphates. Biomaterials. Elsevier Ltd; 2010;31:1465-85.

8. Salinas A, Vallet-Regi M. Bioactive ceramics: from bone grafts to tissue engineering. RSC Adv. 2013;6:56335-52.

9. Le Guéhennec L, Layrolle P, Daculsi G, Redl H, Pandit A, Czernuszka J. A review 
of bioceramics and fibrin sealant. Eur Cell Mater. 2004;8:1-11.

10. Le Nihouannen D, Goyenvalle E, Aguado E, Pilet P, Bilban M, Daculsi G, et al. Hybrid composites of calcium phosphate granules, fibrin glue, and bone marrow for skeletal repair. J Biomed Mater Res A. 2007;81:399-408.

11. Wagner W, Wiltfang J, Pistner H, Yildirim M, Ploder B, Chapman M, et al. Bone formation with a biphasic calcium phosphate combined with fibrin sealant in maxillary sinus floor elevation for delayed dental implant. Clin Oral Implant Res.

2012;23:1112-7.

12. Gasparotto VPO, Landim-Alvarenga FC, Oliveira ALR, Simões GF, Lima-Neto JF, Barraviera B, et al. A new fibrin sealant as a three-dimensional scaffold candidate for mesenchymal stem cells. Stem Cell Res Ther. 2014;5:78.

13. Orsi PR, Landim-Alvarenga FC, Justulin LA, Kaneno R, De Assis Golim M, Dos Santos DC, et al. A unique heterologous fibrin sealant (HFS) as a candidate biological scaffold for mesenchymal stem cells in osteoporotic rats. Stem Cell Res Ther. Stem Cell Research \& Therapy; 2017;8:1-14.

14. Cassaro CV, Justulin LA, De Lima PR, De Assis Golim M, Biscola NP, De Castro $\mathrm{MV}$, et al. Fibrin biopolymer as scaffold candidate to treat bone defects in rats. $\mathrm{J}$ Venom Anim Toxins Incl Trop Dis. 2019;25:1-17.

15. Dos Santos Aciole JM, Dos Santos Aciole GT, Soares LGP, Barbosa AFS, Santos JN, Pinheiro ALB. Bone repair on fractures treated with osteosynthesis, ir laser, bone graft and guided bone regeneration: Histomorfometric study. AIP. 2011;1364:60-5.

16. Gentile P, Chiono V, Tonda-Turo C, Ferreira AM, Ciardelli G. Polymeric membranes for guided bone regeneration. Biotechnol J. 2011;6:1187-97.

17. Khadra M, Kasem N, Haanæs HR, Ellingsen JE, Lyngstadaas SP. Enhancement of bone formation in rat calvarial bone defects using low-level laser therapy. Oral Surg Oral Med Oral Pathol Oral Radiol Endod. 2004;97:693-700.

18. Buchaim DV, Andreo JC, Ferreira Junior RS, Barraviera B, De Castro Rodrigues A, De Cássia MacEdo M, et al. Efficacy of Laser Photobiomodulation on Morphological and Functional Repair of the Facial Nerve. Photomed Laser Surg. 2017;35:442-9.

19. Rosso MP de O, Buchaim DV, Pomini KT, Coletta BB Della, Reis CHB, Pilon JPG, et al. Photobiomodulation therapy (PBMT) applied in bone reconstructive surgery using bovine bone grafts: A systematic review. Materials (Basel). 2019;12:4051.

20. Pinheiro A, Gerbi M. Photo-engineering of bone repair processes. Photomed Laser Surg. 2006;24:169-78.

21. Bosco AF, Faleiros PL, Carmona LR, Garcia VG, Theodoro LH, de Araujo NJ, et 
al. Effects of low-level laser therapy on bone healing of critical-size defects treated with bovine bone graft. J Photochem Photobiol B. Elsevier B.V.; 2016;163:303-10.

22. de Oliveira Gonçalves JB, Buchaim DV, de Souza Bueno CR, Pomini KT, Barraviera B, Júnior RSF, et al. Effects of low-level laser therapy on autogenous bone graft stabilized with a new heterologous fibrin sealant. J Photochem Photobiol B. Elsevier B.V.; 2016;162:663-8.

23. Pomini KT, Buchaim DV, Andreo JC, Rosso MP de O, Della Coletta BB, German ÍJS, et al. Fibrin sealant derived from human plasma as a scaffold for bone grafts associated with photobiomodulation therapy. Int J Mol Sci. 2019;20:1761.

24. Santos P, Cestari T, Paulin J, Martins R, Rocha C, Arantes R, et al. Osteoinductive porous biphasic calcium phosphate ceramic as an alternative to autogenous bone grafting in the treatment of mandibular bone critical-size defects. $J$ Biomed Mater Res B Appl Biomater. 2018;106:1546-57.

25. Paini S, Bighetti ACC, Cestari TM, Arantes RVN, Santos PS, Mena-Laura EE, et al. Concentration-dependent effects of latex F1-protein fraction incorporated into deproteinized bovine bone and biphasic calcium phosphate on the repair of criticalsize bone defects. J Biomed Mater Res. 2020;1-16.

26. Bastos de Carvalho F, Aciole GTS, Aciole JMS, Silveira, Jr. L, Nunes dos Santos $\mathrm{J}$, Pinheiro ALB. Assessment of bone healing on tibial fractures treated with wire osteosynthesis associated or not with infrared laser light and biphasic ceramic bone graft (HATCP) and guided bone regeneration (GBR): Raman spectroscopy study. Mech Low-Light Ther VI. 2011;7887:78870T.

27. Bernabé PFE, Melo LGN, Cintra LTA, Gomes-Filho JE, Dezan E, Nagata MJH. Bone healing in critical-size defects treated with either bone graft, membrane, or a combination of both materials: A histological and histometric study in rat tibiae. Clin Oral Implant Res. 2012;23:384-8.

28. Costa NMF, Yassuda DH, Sader MS, Fernandes GVO, Soares GDA, Granjeiro JM. Osteogenic effect of tricalcium phosphate substituted by magnesium associated with Genderm $\AA^{\circledR}$ membrane in rat calvarial defect model. Mater Sci Eng C Mater Biol Appl. Elsevier B.V.; 2016;61:63-71.

29. Sakkas A, Wilde F, Heufelder M, Winter K, Schramm A. Autogenous bone grafts in oral implantology-is it still a "gold standard"? A consecutive review of 279 patients with 456 clinical procedures. Int J Implant Dent. International Journal of Implant Dentistry; 2017;3:23.

30. Chung H, Dai T, Sharma S, Huang Y, Carroll J, MR H. The nuts and bolts of lowlevel laser (light) therapy. Ann Biomed Eng. 2012;40:516-33.

31. Torres CS, Dos Santos JN, Monteiro JSC, Amorim PGM, Pinheiro ALB. Does the use of laser photobiomodulation, bone morphogenetic proteins, and guided bone regeneration improve the outcome of autologous bone grafts? An in vivo study in a rodent model. Photomed Laser Surg. 2008;26:371-7. 
32. Zein R, Selting W, Hamblin MR. Review of light parameters and photobiomodulation efficacy: dive into complexity. J Biomed Opt. 2018;23:1-17.

33. Fávaro-Pípi E, Ribeiro DA, Ribeiro JU, Bossini $P$, Oliveira $P$, Parizotto NA, et al. Low-level laser therapy induces differential expression of osteogenic genes during bone repair in rats. Photomed Laser Surg. 2011;29:311-7.

34. Gosain AK, Song L, Yu P, Mehrara BJ, Maeda CY, Gold LI, et al. Osteogenesis in cranial defects: Reassessment of the concept of critical size and the expression of TGF- $\beta$ isoforms. Plast Reconstr Surg. 2000;106:360-71.

35. Zong C, Xue D, Yuan W, Wang W, Shen D, Tong X, et al. Reconstruction Of Rat Calvarial Defects With Human Mesenchymal Stem Cells and Osteoblast-Like Cells in Poly-Lactic-Co-Glycolic Acid Scaffolds. Eur Cell Mater. 2010;20:109-20.

36. Mountziaris PM, Spicer PP, Kasper FK, Mikos AG. Harnessing and modulating inflammation in strategies for bone regeneration. Tissue Eng Part B Rev. 2011;17:393-402.

37. Schmidt-Bleek K, Kwee BJ, Mooney DJ, Duda GN. Boon and Bane of Inflammation in Bone Tissue Regeneration and Its Link with Angiogenesis. Tissue Eng Part B Rev. 2015;21:354-64.

38. Moreira ASB, Pastoreli MT, Damasceno LHF, Defino HLA. Estudo experimental da influência das dimensões dos grânulos de hidroxiapatita na integração óssea. Acta ortop bras. 2003;11:240-50.

39. Yoshikawa H, Tamai N, Murase T, Myoui A. Interconnected porous hydroxyapatite ceramics for bone tissue engineering. J R Soc Interface. 2009;6.

40. Kim BS, Sung HM, You HK, Lee J. Effects of fibrinogen concentration on fibrin glue and bone powder scaffolds in bone regeneration. J Biosci Bioeng. Elsevier Ltd; 2014;118:469-75.

41. Buchaim DV, Cassaro CV, Shindo JVTC, Coletta BB Della, Pomini KT, De Oliveira Rosso MP, et al. Unique heterologous fibrin biopolymer with hemostatic, adhesive, sealant, scaffold and drug delivery properties: A systematic review. J Venom Anim Toxins Incl Trop Dis. 2019;25:1-15.

42. Creste CFZ, Orsi PR, Landim-Alvarenga FC, Justulin LA, De Assis Golim M, Barraviera $B$, et al. Highly effective fibrin biopolymer scaffold for stem cells upgrading bone regeneration. Mater. 2020;13:2747.

43. De Lima Taga ML, Granjeiro JM, Cestari TM, Taga R. Healing of critical-size cranial defects in guinea pigs using a bovine bone-derived resorbable membrane. Int J Oral Max Impl. 2008;23:427-36.

44. Kitayama S, Wong LO, Ma L, Hao J, Kasugai S, Lang NP, et al. Regeneration of rabbit calvarial defects using biphasic calcium phosphate and a strontium hydroxyapatite-containing collagen membrane. Clin Oral Implant Res. 2016;27:e206- 
14.

45. Rosso MP de O, Rosa Júnior GM, Buchaim DV, German IJS, Pomini KT, de Souza RG, et al. Stimulation of morphofunctional repair of the facial nerve with photobiomodulation, using the end-to-side technique or a new heterologous fibrin sealant. J Photochem Photobiol B. Elsevier; 2017;175:20-8.

46. De Bari C, Dell'Accio F, Karystinou A, Guillot P V., Fisk NM, Jones EA, et al. A biomarker-based mathematical model to predict bone-forming potency of human synovial and periosteal mesenchymal stem cells. Arthritis Rheum. 2008;58:240-50.

47. Florencio-Silva R, Sasso GR da S, Sasso-Cerri E, Simões MJ, Cerri PS. Biology of Bone Tissue: Structure, Function, and Factors That Influence Bone Cells. Biomed Res Int. 2015;2015:1-18.

48. Karu T, Pyatibrat L, Kalendo G. Irradiation with HeNe laser increases ATP level in cells cultivated in vitro. J Photochem Photobiol. 1995;27:219-23.

49. Pomini KT, Andreo JC, Rodrigues ADC, Gonçalves JBDO, Daré LR, German IJS, et al. Effect of Low-Intensity Pulsed Ultrasound on Bone Regeneration Biochemical and Radiologic Analyses. J Ultrasound Med. 2014;4:713-7.

50. Deniz E, Arslan A, Diker N, Olgac V, Kilic E. Evaluation of light-emitting diode photobiomodulation on bone healing of rat calvarial defects. Biotechnol Biotechnol Equip. Taylor \& Francis; 2015;29:758-65.

51. Rosso MPDO, Oyadomari AT, Pomini KT, Botteon B, Coletta D, Cosin T, et al. Photobiomodulation Therapy Associated with Heterologous Fibrin Biopolymer and Bovine Bone Matrix Helps to Reconstruct Long Bones. Biomolecules. 2020;10:1-17. 

3 DISCUSSION 



\section{DISCUSSION}

Bone loss can be caused by injuries, orthopedic trauma, diseases such as tumors, osteoporosis, osteonecrosis and alterations, and in many cases is irreversible with adapted and psychological changes in the individual's life (SPICER et al., 2012).

Since the techniques frequently used, such as the autogenous graft, can involve invasive procedures and are subject to complications, studies in the area of tissue engineering have been growing in search of new alternatives capable of stimulating tissue regeneration (O'BRIEN, 2011; LOI et al., 2016).

Due to the absence of reports on the association of low intensity laser and the association of GenPhos XP ${ }^{\circledR}$ biphasic bioceramics and the heterologous fibrin biopolymer, the present study used the critical defect model created in rat calvaria to evaluate, for the first time, the effects of laser photobiomodulation therapy (PBMT) on guided bone regeneration using biphasic calcium phosphate as a bone substitute associated with fibrin biopolymer. The results showed that the laser protocol, together with the biomaterials, showed effects that collaborate with the regenerative process of the skull cap of rats.

The experimental model of rats was chosen because it is an animal with high reproduction, low cost, allowing its use in greater numbers and thus obtaining relevant statistical data, as well as the reduced amount of materials to be tested, and high performance in carrying out different analyses (SCHMITZ; HOLLINGER, 1986; EINHORN, 1999; SPICER et al., 2012).

Calvaria has been used in several studies due to its embryological similarity, that is, similarity with the craniomaxillofacial area. In addition, it is an area with stability without the need for fixation as in long bones, which facilitates the accommodation of grafts and allows to obtain a uniform and standardized defect (SCHMITZ et al., 1990; SCHLEGEL et al., 2006; GOMES; FERNANDES, 2011; SPICER et al., 2012).

In the present study, the $5 \mathrm{~mm}$ defects in the parietal bones showed, through microtomographic analysis, a bone formation limited to the margins and the absence of closure of the lesion, which indicates that it is a critical size defect defined by the smallest intraosseous wound unable to fully regenerate during the study period (GOSAIN et al., 2000). 
The main objective of the research was to evaluate the effect of the association of biomaterials under laser biostimulation on the defect, thus prioritizing the least amount of animals and groups possible, following the theory of William Russell and Rex Burch (1959) of the 3 Rs: reduction, replacement and refinement (FLECKNELL, 2002).

Thus, we opted for the absence of groups with empty cavities, which are frequently portrayed in the literature (LUVIZUTO et al., 2011; FERREIRA et al., 2015; AUERSVALD et al., 2017). Likewise, to make the research feasible, the groups were divided into periods of 14 and 42 days, justified in the literature that the observation time for non-critical defects does not exceed 6 weeks, therefore, from that time, there would be no significant changes in regeneration (VAN GRIENSVEN, 2015).

The choice of the AIGaAs laser and the parameters such as $830 \mathrm{~nm}$ wavelength, $30 \mathrm{~mW}$ power and $6.2 \mathrm{~J} / \mathrm{cm}^{2}$ energy density occurred due to previous studies by our group of researchers and the satisfactory results obtained in tissue regeneration (DE OLIVEIRA GONÇALVES et al., 2016; ROSSO et al., 2017; BUCHAIM et al., 2019; POMINI et al., 2019).

In the microtomographic, histological and histomorphometric analyses, it was evident that the irradiated animals had a higher concentration of newly formed bone and a more advanced repair process compared to the non-irradiated animals. Thus, such a finding can be pointed out, at a wavelength of $830 \mathrm{~nm}$, which guaranteed greater absorption of electromagnetic energy by the target tissue with minimal loss (SELLA et al., 2015).

The increase in new bone tissue in all experimental groups at 42 days may also have been facilitated by the association of ceramics, in the ratio of 70:30 (HA: $\beta$-TCP), because it has hydroxyapatite with osteoconductive property and slow resorption and the beta tricalcium phosphate, responsible for faster resorption (LEGEROS et al., 2003; PRIPATNANONT et al., 2016).

Regarding guided bone regeneration, its use in the present experiment is justified since it is a necessary procedure to protect the surgical area against the invagination of surrounding soft tissues, providing the formation of adequate space for the proliferation of osteogenic cells (DAHLIN et al., 2015), in addition to presenting biocompatibility, causing no immunogenic reactions as reported in preliminary studies (KITAYAMA et al., 2016; TONETTO et al., 2016). 
4 CONCLUSION 



\section{CONCLUSION}

The results of the present study show that laser photobiomodulation therapy provided positive effects on guided bone regeneration when associated with fibrin biopolymer and biphasic calcium phosphate, accelerating the remodeling process in critical calvaria defects in rats. 

REFERENCES 



\section{REFERENCES}

AUERSVALD, C. M. et al. The local administration of parathyroid hormone encourages the healing of bone defects in the rat calvaria: Micro-computed tomography, histological and histomorphometric evaluation. Arch Oral Biol, v. 79, p. 14-19, 2017.

BARROS, L. C. et al. A new fibrin sealant from crotalus durissus terrificus venom: Applications in medicine. J Toxicol Environ Health B Crit Rev, v. 12, n. 8, p. 553571, 2009.

BUCHAIM, D. V. et al. Efficacy of Laser Photobiomodulation on Morphological and Functional Repair of the Facial Nerve. Photomed Laser Surg, v. 35, n. 8, p. 442449, 2017.

BUCHAIM, D. V. et al. Unique heterologous fibrin biopolymer with hemostatic, adhesive, sealant, scaffold and drug delivery properties: A systematic review. J Venom Anim Toxins Incl Trop Dis., v. 25, n. October 2019, p. 1-15, 2019.

CASSARO, C. V. et al. Fibrin biopolymer as scaffold candidate to treat bone defects in rats. J Venom Anim Toxins Incl Trop Dis., v. 25, n. November, p. 1-17, 2019.

CHUNG, H. et al. The nuts and bolts of low-level laser (light) therapy. Ann Biomed Eng., v. 40, n. 2, p. 516-533, 2012.

CUNHA, M. R. et al. Hydroxyapatite and a New Fibrin Sealant Derived from Snake Venom as Scaffold to Treatment of Cranial Defects in Rats. Mat. Res., v. 18, n. 1, p. 196-203, 2015.

DAHLIN, C. et al. Bone tissue modelling and remodelling following guided bone regeneration in combination with biphasic calcium phosphate materials presenting different microporosity. Clin Oral Implants Res., v. 26, n. 7, p. 814-822, 2015.

DE OLIVEIRA GONÇALVES, J. B. et al. Effects of low-level laser therapy on autogenous bone graft stabilized with a new heterologous fibrin sealant. $\mathbf{J}$ Photochem Photobiol B., v. 162, p. 663-668, 2016.

DIMITRIOU, R. et al. The role of barrier membranes for guided bone regeneration and restoration of large bone defects: Current experimental and clinical evidence. BMC Med., v. 10, p. 81, 2012.

DOROZHKIN, S. V. Bioceramics of calcium orthophosphates. Biomaterials, v. 31, n. 7, p. 1465-1485, 2010.

DOROZHKIN, S. V. Biphasic, triphasic and multiphasic calcium orthophosphates. Acta Biomater., v. 8, n. 3, p. 963-977, 2012.

EBRAHIMI, M.; BOTELHO, M. G.; DOROZHKIN, S. V. Biphasic calcium phosphates bioceramics (HA/TCP): Concept, physicochemical properties and the impact of standardization of study protocols in biomaterials research. Mater Sci Eng C Mater 
Biol Appl., v. 71, p. 1293-1312, 2017.

EINHORN, T. A. Clinically applied models of bone regeneration in tissue engineering research. Clin. Orthop. Relat. Res., n. 367 SUPPL., p. 59-67, 1999.

ELGALI, I. et al. Guided bone regeneration: materials and biological mechanisms revisited. Eur J Oral Sci., v. 125, n. 5, p. 315-337, 2017.

FERREIRA, A. S. S. B. S. et al. A success in Toxinology translational research in Brazil: Bridging the gap. Toxicon, v. 69, p. 50-54, 2013.

FERREIRA, L. B. et al. Evaluation of bone repair of critical size defects treated with simvastatin-loaded poly(lactic-co-glycolic acid) microspheres in rat calvaria. $\mathbf{J}$

Biomater Appl., v. 29, n. 7, p. 965-976, 2015.

FERREIRA, R. S. J. et al. Heterologous fibrin sealant derived from snake venom: From bench to bedside - an overview. J Venom Anim Toxins Incl Trop Dis., v. 23, n. 1, p. 1-12, 2017.

FLECKNELL, P. Replacement, reduction and refinement. ALTEX ALTERN TIEREXP., v. 19, n. 2, p. 73-78, 2002.

GARCÍA-GARETA, E.; COATHUP, M. J.; BLUNN, G. W. Osteoinduction of bone grafting materials for bone repair and regeneration. Bone, v. 81, p. 112-121, 2015.

GENTILE, P. et al. Polymeric membranes for guided bone regeneration. Biotechnol J., v. 6, n. 10, p. 1187-1197, 2011.

GERBI, M. E. M. D. M. et al. Photobiomodulation Therapy in Bone Repair Associated with Bone Morphogenetic Proteins and Guided Bone Regeneration: A Histomorphometric Study. Photomed Laser Surg., v. 36, n. 11, p. 581-588, 2018.

GOMES, P. S.; FERNANDES, M. H. Rodent models in bone-related research: The relevance of calvarial defects in the assessment of bone regeneration strategies. Lab. Anim., v. 45, n. 1, p. 14-24, 2011.

GOSAIN, A. K. et al. Osteogenesis in cranial defects: Reassessment of the concept of critical size and the expression of TGF- $\beta$ isoforms. Plast Reconstr Surg., v. 106, n. 2 , p. $360-371,2000$.

JENSEN, S. S. et al. Comparative study of biphasic calcium phosphates with different HA/TCP ratios in mandibular bone defects. A long-term histomorphometric study in minipigs. J Biomed Mater Res B Appl Biomater., v. 90 B, n. 1, p. 171-181, 2009.

KITAYAMA, S. et al. Regeneration of rabbit calvarial defects using biphasic calcium phosphate and a strontium hydroxyapatite-containing collagen membrane. Clin. Oral Implants Res., v. 27, n. 12, p. e206-e214, 2016.

KUBOTA, J.; OHSHIRO, T. The Effects of Diode Laser Lllt on Flap Survival: 
Measurement of Flap Microcirculation with Laser Speckle Flowmetry. Laser Therapy, v. 14, p. 55-60, 2004.

LEGEROS, R. Calcium phosphate-based osteoinductive materials. Chem Rev., v. 108, n. 11, p. 4742-4753, 2008.

LEGEROS, R. Z. et al. Biphasic calcium phosphate bioceramics: Preparation, properties and applications. J Mater Sci Mater Med., v. 14, n. 3, p. 201-209, 2003.

LIU, X. et al. Effect of lower-level laser therapy on rabbit tibial fracture. Photomed Laser Surg, v. 25, n. 6, p. 487-494, 2007.

LOI, F. et al. Inflammation, fracture and bone repair. Bone, v. 86, p. 119-130, 2016.

LUVIZUTO, E. R. et al. The effect of BMP-2 on the osteoconductive properties of $\beta$ tricalcium phosphate in rat calvaria defects. Biomaterials, v. 32, n. 15, p. 38553861, 2011.

MUSSTTAF, R. A.; JENKINS, D. F. L.; JHA, A. N. Assessing the impact of low level laser therapy (LLLT) on biological systems: a review. Int J Radiat Biol, v. 95, n. 2, p. 120-143, 2019.

O'BRIEN, F. J. Biomaterials \& scaffolds for tissue engineering. Mater. Today, v. 14, n. 3, p. 88-95, 2011.

PINHEIRO, A.; GERBI, M. Photo-engineering of bone repair processes. Photomed Laser Surg., v. 24, n. 2, p. 169-178, 2006.

POMINI, K. T. et al. Fibrin sealant derived from human plasma as a scaffold for bone grafts associated with photobiomodulation therapy. Int J Mol Sci., v. 20, n. 7, p. 1761, 2019.

PRIPATNANONT, P. et al. Bone Regeneration Potential of Biphasic Nanocalcium Phosphate with High Hydroxyapatite/Tricalcium Phosphate Ratios in Rabbit Calvarial Defects. Int J Oral Maxillofac Implants., v. 31, n. 2, p. 294-303, 2016.

RETZEPI, M.; DONOS, N. Guided Bone Regeneration: Biological principle and therapeutic applications. Clin Oral Implants Res., v. 21, n. 6, p. 567-576, 2010.

ROSSO, M. P. de O. et al. Stimulation of morphofunctional repair of the facial nerve with photobiomodulation, using the end-to-side technique or a new heterologous fibrin sealant. J Photochem Photobiol B., v. 175, p. 20-28, 2017.

ROSSO, M. P. de O. et al. Photobiomodulation therapy (PBMT) applied in bone reconstructive surgery using bovine bone grafts: A systematic review. Materials, v. 12, n. 24, p. 4051, 2019.

SAKKAS, A. et al. Autogenous bone grafts in oral implantology-is it still a "gold standard"? A consecutive review of 279 patients with 456 clinical procedures. Int $\mathbf{J}$ Implant Dent., v. 3, n. 1, p. 23, 2017. 
SALINAS, A.; VALLET-REGI, M. Bioactive ceramics: from bone grafts to tissue engineering. RSC Adv., v. 6, n. 61, p. 56335-56352, 2013.

SCHLEGEL, K. A. et al. The monocortical critical size bone defect as an alternative experimental model in testing bone substitute materials. Oral Surg Oral Med Oral Pathol Oral Radiol Endod., v. 102, n. 1, p. 7-13, 2006.

SCHMITZ, J. P. et al. Characterization of Rat Calvarial Nonunion Defects. Acta Anat, v. 138, p. 185-192, 1990.

SCHMITZ, J. P.; HOLLINGER, J. O. The critical size defect as an experimental model for craniomandibulofacial nonunions. Clin. Orthop. Relat. Res., v. NO. 205, p. 299-308, 1986.

SELLA, V. R. G. et al. Effect of low-level laser therapy on bone repair: a randomized controlled experimental study. Lasers Med Sci., v. 30, n. 3, p. 1061-1068, 2015.

SPICER, P. P. et al. Evaluation of bone regeneration using the rat critical size calvarial defect. Nat Protoc, v. 7, n. 10, p. 1918-1929, 2012.

STRATTON, S. et al. Bioactive polymeric scaffolds for tissue engineering. Bioact Mater., v. 1, n. 2, p. 93-108, 2016.

TONETTO, A. et al. Effects of chrondro-osseous regenerative compound associated with local treatments in the regeneration of bone defects around implants: an in vivo study. Clin Oral Investig., v. 20, n. 2, p. 267-274, 2016.

VAN BLITTERSWIJK, C. A. et al. Macropore tissue ingrowth: a quantitative and qualitative study on hydroxyapatite ceramic. Biomaterials, v. 7, n. 2, p. 137-143, 1986.

VAN GRIENSVEN, M. Preclinical testing of drug delivery systems to bone. Adv Drug Deliv Rev., v. 94, p. 151-164, 2015. 
ANNEXES 



\section{ANNEXES}

Annex A: Approval of Animal Ethical Committee

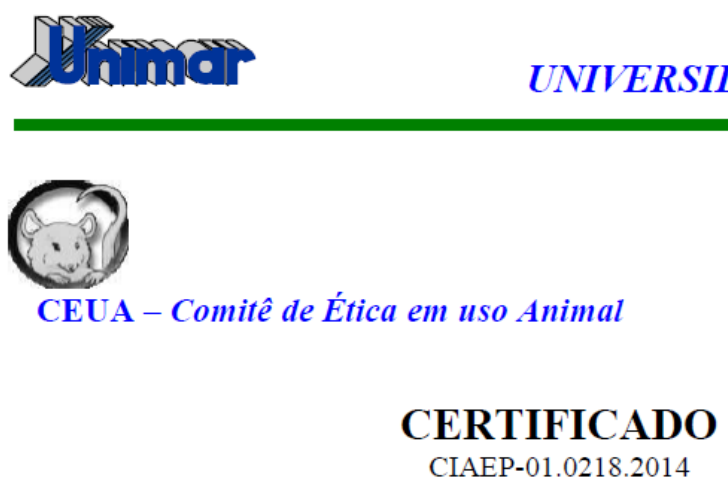

Certificamos que o projeto intitulado "Efeitos da terapia por laser de baixa potência no processo de defeitos ósseos preenchidos por enxerto ósseo cerâmico bifásico associado ao novo biopolímero de fibrina" que envolve produção, manutenção e /ou utilização de animais pertencentes ao filo Chordata, subfilo Vertebrata (exceto o homem), para fins de pesquisa cientifica encontra-se de acordo com os preceitos da lei $\mathrm{n}^{\circ} 11794$, de 8 de outubro de 2008, do Decreto no 6.899, de 15 de julho de 2009, e com as normas editadas pelo Conselho Nacional de Controle de Experimentação Animal (CONCEA), foi aprovado pelo COMITÊ DE ÉTICA EM USO ANIMAL (CEUA) DA UNIVERSIDADE DE MARÍLIA.

\begin{tabular}{|l|l|}
\hline Vigência do projeto & Agosto a julho de 2019 \\
\hline Espécie/linhagem & Ratos Wistar \\
\hline Número de animais & 30 \\
\hline Peso / Idade & Ratos adultos - 250gr \\
\hline Sexo & Machos \\
\hline
\end{tabular}

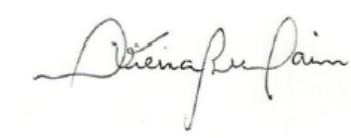

Profa. Dra. Daniela Vieira Buchaim Coordenadora do CEUA 
Annex B: Certificate of English Review

$09 / 24 / 20$

\section{Certification of English Review}

To whom it may concern,

My name is Louis Francisco Vega (CNPJ:17.197.009/001-37) and I am a Native English speaking American residing in Brazil. I have been executing English reviews for Scientific Articles for various foreign authors in the field of Dentistry, Speech Pathology and Audiology and other Sciences since August of 2011. I have also freelanced as a reviewer with the Bauru School of Dentistry-University of São Paulo, Bauru, S.P. FOB -USP Journal of Applied Oral Science (JAOS).

This letter is to certify that I have performed an English review on the $24^{\text {th }}$ of September, 2020 on an article entitled "Effects of photobiomodulation therapy on the bone regeneration process guided in defects filled by biphasic calcium phosphate associated with fibrin biopolymer" written by B.B.D.Coletta, T.B.Jacob, L.A.D.C.Moreira, K.T.P.Rocha, D.V.Buchaim, R.G. Eleutério, D.D.Roque, M.P.D.O.Rosso, J.V.T.C.Shindo, M.P.Alcalde, M.A.H.Duarte, R.S.Ferreira Jr, B.Barraviera and R.L.Buchaim.

I am confirming that I have edited the Scientific Abstract that is being submitted with this letter of certification, and in my professional opinion, deem it noteworthy for consideration for publication.

Sincerely,
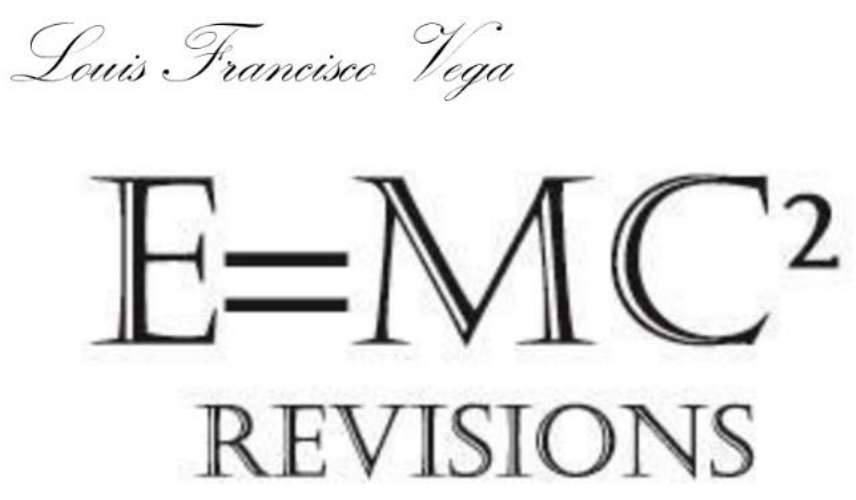

(14) $9635-9684$ (14) $8152-0544$

louisfranciscovega@gmail.com

Bauru, S.P., Brasil 